\title{
Cochrane
}

Library

Cochrane Database of Systematic Reviews

\section{Single dose oral etoricoxib for acute postoperative pain in adults} (Review)

Clarke R, Derry S, Moore RA

Clarke R, Derry S, Moore RA.

Single dose oral etoricoxib for acute postoperative pain in adults.

Cochrane Database of Systematic Reviews 2014, Issue 5. Art. No.: CD004309.

DOI: 10.1002/14651858.CD004309.pub4.

www.cochranelibrary.com 
TABLE OF CONTENTS

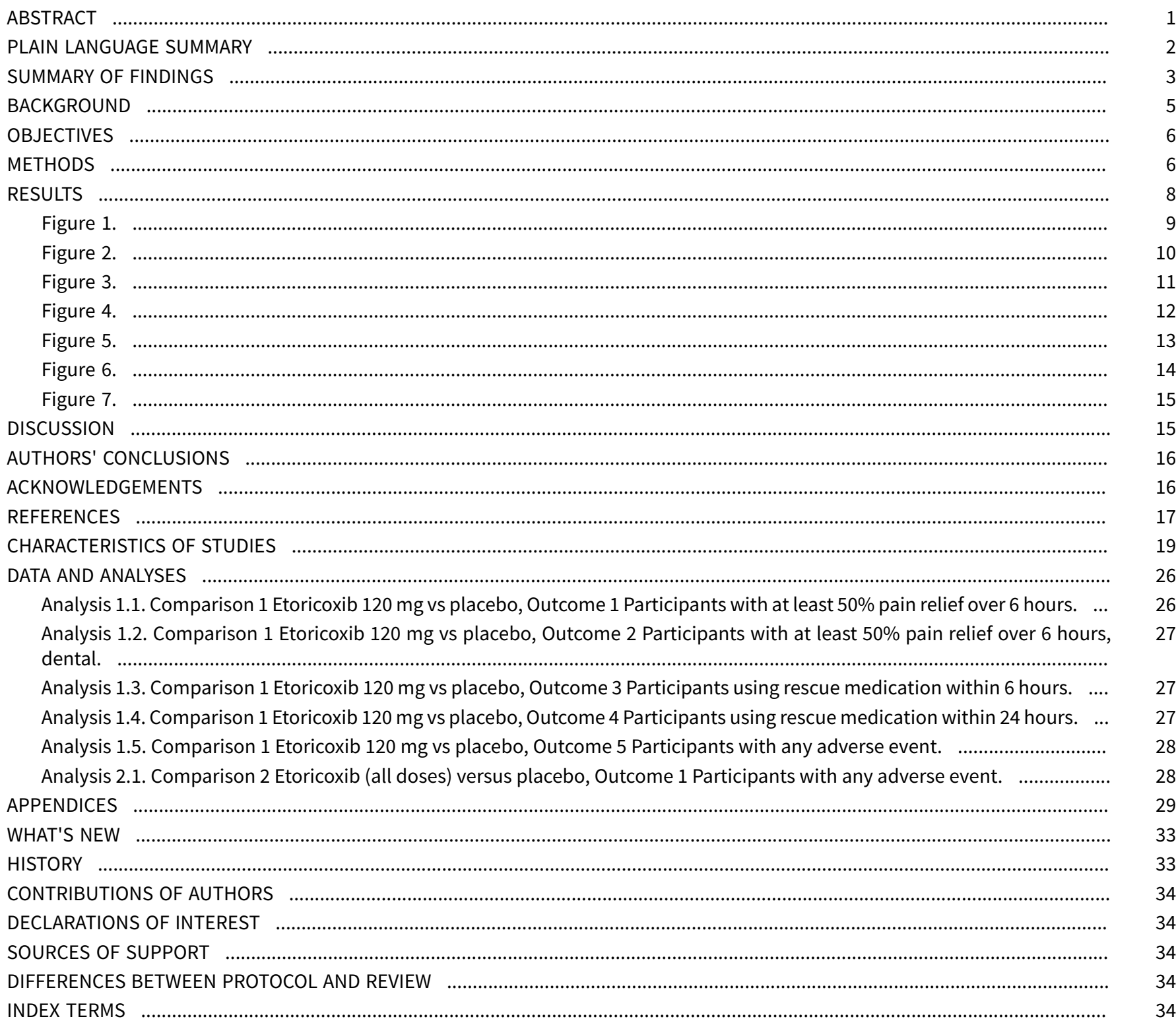


[Intervention Review]

\section{Single dose oral etoricoxib for acute postoperative pain in adults}

Rachel Clarke ${ }^{1}$, Sheena Derry², R Andrew Moore ${ }^{3}$

1Pain Research and Nuffield Department of Clinical Neurosciences, University of Oxford, Oxford, UK. 20xford, UK. ${ }^{3}$ Plymouth, UK

Contact: Sheena Derry, Oxford, Oxfordshire, UK. sheena.derry@retired.ox.ac.uk.

Editorial group: Cochrane Pain, Palliative and Supportive Care Group.

Publication status and date: Stable (no update expected for reasons given in 'What's new'), published in Issue 5, 2019.

Citation: Clarke R, Derry S, Moore RA. Single dose oral etoricoxib for acute postoperative pain in adults. Cochrane Database of Systematic Reviews 2014, Issue 5. Art. No.: CD004309. DOI: 10.1002/14651858.CD004309.pub4.

Copyright @ 2019 The Cochrane Collaboration. Published by John Wiley \& Sons, Ltd.

\section{A B S T R A C T}

\section{Background}

This is an updated version of the original Cochrane review first published in Issue 2, 2009, and updated in Issue 4, 2012.

Etoricoxib is a selective cyclo-oxygenase-2 (COX-2) inhibitor licensed for the relief of chronic pain in osteoarthritis and rheumatoid arthritis, and acute pain in some jurisdictions. This class of drugs is believed to be associated with fewer upper gastrointestinal adverse effects than conventional non-steroidal anti-inflammatory drugs (NSAIDs).

\section{Objectives}

To assess the efficacy and adverse effects of single dose etoricoxib for acute postoperative pain using methods that permit accurate comparison with other analgesics evaluated in the same way, using criteria of efficacy recommended by in-depth studies at the individual patient level.

\section{Search methods}

We searched the Cochrane Central Register of Controlled Trials (CENTRAL), MEDLINE, EMBASE, the Oxford Pain Database, www.clinicaltrials.gov, and reference lists of articles. The date of the most recent search was 31 January 2014.

\section{Selection criteria}

Randomised, double-blind, placebo-controlled clinical trials of single dose, oral etoricoxib for acute postoperative pain in adults.

\section{Data collection and analysis}

Two review authors independently considered studies for inclusion in the review, assessed quality, and extracted data. We used the area under the pain relief versus time curve to derive the proportion of participants prescribed etoricoxib or placebo with at least $50 \%$ pain relief over six hours, using validated equations. We calculated relative risk (RR) and number needed to treat to benefit (NNT). We used information on use of rescue medication to calculate the proportion of participants requiring rescue medication and the weighted mean of the median time to use. We also collected information on adverse events.

\section{Main results}

We identified no new studies for this updated review, which includes six studies with 1214 participants in comparisons of etoricoxib with placebo. All six studies reported on the $120 \mathrm{mg}$ dose (798 participants in a comparison with placebo). Sixty-six per cent of participants with etoricoxib $120 \mathrm{mg}$ and $12 \%$ with placebo reported at least 50\% pain relief (NNT 1.8 (1.7 to 2.0); high-quality evidence). For dental studies only, the NNT was 1.6 (1.5 to 1.8). A single dose of $90 \mathrm{mg}$ produced similar results in one large trial. Other doses (60, 180, and $240 \mathrm{mg}$ ) were each studied in only one treatment arm. 
Significantly fewer participants used rescue medication over 24 hours when taking etoricoxib 120 mg than placebo (NNT to prevent remedication 2.2 (1.9 to 2.8)), and the median time to use of rescue medication was 20 hours for etoricoxib and two hours for placebo. Adverse events were reported at a similar rate to placebo (moderate-quality evidence), with no serious events.

\section{Authors' conclusions}

Single-dose oral etoricoxib produces high levels of good quality pain relief after surgery, and adverse events did not differ from placebo in these studies. The $120 \mathrm{mg}$ dose is as effective as, or better than, other commonly used analgesics.

\section{PLAIN LANGUAGE SUMMARY}

\section{Single dose oral etoricoxib for acute postoperative pain in adults}

Acute pain is often felt soon after injury. Most people who have surgery have moderate or severe pain afterwards. People with pain are used to test painkillers. They have often had wisdom teeth removed. The pain is often treated with pain killers taken by mouth. Results can be applied to other forms of acute pain.

A series of reviews looks at how good painkillers are. This review looks at a drug called etoricoxib. This is one of a type of pain killer called an NSAID (non-steroidal anti-inflammatory drug). The amount of pain relief experienced depends on the dose taken.

We found six clinical trials with 1214 people. A single $120 \mathrm{mg}$ dose of etoricoxib produced useful pain relief in 7 in 10 (66\%) people with moderate or severe pain, compared with just over 1 in 10 (12\%) with placebo. A single $90 \mathrm{mg}$ dose produced similar results in one large trial. Pain relief lasted for 20 hours in half of people treated.

Adverse events occurred at similar rates with etoricoxib and placebo in these single-dose studies. No serious adverse events or withdrawals due to adverse events occurred with etoricoxib. 


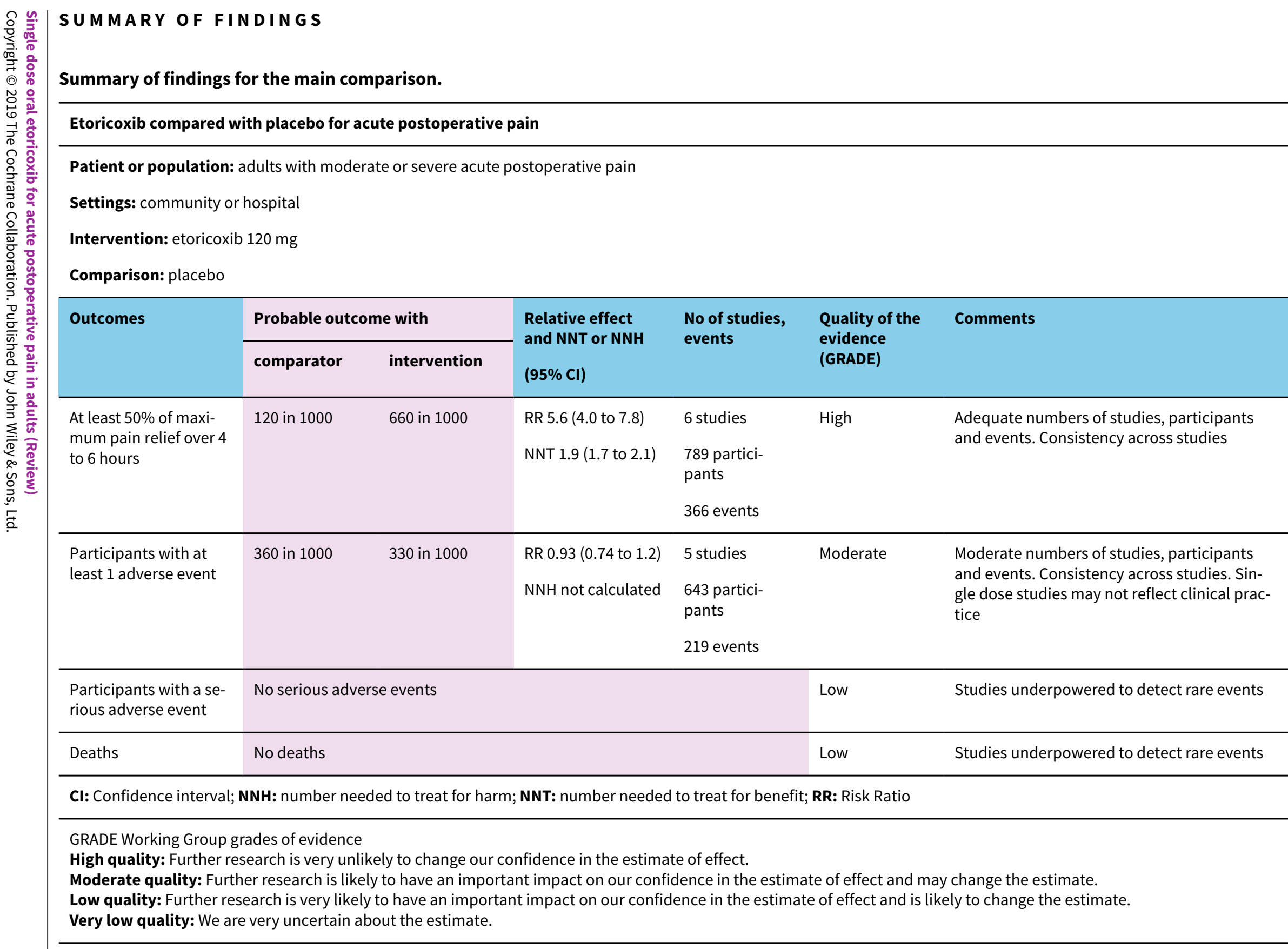




\section{B A C K G R O U N D}

This is an updated version of the original Cochrane review, 'Single dose oral etoricoxib for acute postoperative pain in adults', first published in Issue 2, 2009 (Clarke 2009), and updated in Issue 4, 2012 (Clarke 2012).

\section{Description of the condition}

Acute pain occurs as a result of tissue damage either accidentally due to an injury or as a result of surgery. Acute postoperative pain is a manifestation of inflammation due to tissue injury. The management of postoperative pain and inflammation is a critical component of patient care. The aim of this series of reviews is to present evidence for relative analgesic efficacy through indirect comparisons with placebo, in very similar trials performed in a standard manner, with very similar outcomes, and over the same duration. Such relative analgesic efficacy does not in itself determine choice of drug for any situation or patient, but guides policy-making at the local level. The series includes wellestablished analgesics such as paracetamol (Toms 2008), naproxen (Derry 2009a), diclofenac (Derry 2009b), and ibuprofen (Derry 2009c), and newer cyclo-oxygenase-2 selective analgesics, such as celecoxib (Derry 2013) and lumiracoxib (Roy 2010). An overview brings together the results from all the individual drug reviews (Moore 2011a).

Single dose trials in acute pain are commonly short in duration, rarely lasting longer than 12 hours. The numbers of participants are small, allowing no reliable conclusions to be drawn about safety. To show that the analgesic is working it is necessary to use placebo (McQuay 2005). There are clear ethical considerations in doing this. These ethical considerations are answered by using acute pain situations where the pain is expected to go away, and by providing additional analgesia, commonly called rescue analgesia, if the pain has not diminished after about an hour. This is reasonable, because not all participants given an analgesic will have significant pain relief. Approximately $18 \%$ of participants given placebo will have significant pain relief (Moore 2006), and up to $50 \%$ may have inadequate analgesia with active medicines. The use of additional or rescue analgesia is hence important for all participants in trials.

Clinical trials measuring the efficacy of analgesics in acute pain have been standardised over many years. Trials have to be randomised and double-blind. Typically, in the first few hours or days after an operation, patients develop pain that is moderate to severe in intensity, and will then be given the test analgesic or placebo. Pain is measured using standard pain intensity scales immediately before the intervention, and then using pain intensity and pain relief scales over the following four to six hours for shorteracting drugs, and up to 12 or 24 hours for longer-acting drugs. Pain relief of half the maximum possible pain relief or better (at least $50 \%$ pain relief) is typically regarded as a clinically useful outcome. For patients given rescue medication it is usual for no additional pain measurements to be made, and for all subsequent measures to be recorded as initial pain intensity or baseline (zero) pain relief (baseline observation carried forward). This process ensures that analgesia from the rescue medication is not wrongly ascribed to the test intervention. In some trials the last observation is carried forward, which gives an inflated response for the test intervention compared to placebo, but the effect has been shown to be negligible over four to six hours (Moore 2005a). Patients usually remain in the hospital or clinic for at least the first six hours following the intervention, with measurements supervised, although they may then be allowed home to make their own measurements in trials of longer duration.

Knowing the relative efficacy of different analgesic drugs at various doses can be helpful. Results from completed reviews of many different analgesics have been brought together to facilitate (indirect) comparisons in an overview (Moore 2011a), and analgesics relevant for dentistry are discussed in Barden 2004a and Derry 2011.

\section{Description of the intervention}

Selective cyclo-oxygenase-2 inhibitors (COX-2 inhibitors or 'coxibs') were developed to address the problem of upper gastrointestinal bleeding associated with traditional non-steroidal anti-inflammatory drugs (NSAIDs) (Hawkey 2001). Etoricoxib (sold worldwide under the brand name of Arcoxia, and in Italy as Algix and Tauxib) is one of the second generation of coxibs and is used to treat pain in chronic conditions, such as rheumatoid arthritis and osteoarthritis, ankylosing spondylitis, and low back pain, and also in acute pain and gout. It is available by prescription only as $30 \mathrm{mg}$, $60 \mathrm{mg}, 90 \mathrm{mg}$, and $120 \mathrm{mg}$ tablets in many parts of the world, but is not licensed for use in the US, due to concerns about safety. In chronic conditions the daily dose is usually $30 \mathrm{mg}$ to $90 \mathrm{mg}$ once daily, and in acute conditions 90 or $120 \mathrm{mg}$ once daily (for up to a week). In primary care in England in 2012, there were almost 50,000 prescriptions for the $120 \mathrm{mg}$ dose, and about 150,000 each for the $60 \mathrm{mg}$ and $90 \mathrm{mg}$ doses (PACT 2013).

The standard licensed dose of etoricoxib for acute pain is $120 \mathrm{mg}$ in most countries, but a lower dose of $90 \mathrm{mg}$ may be recommended in others.

\section{How the intervention might work}

NSAIDs have pain-relieving, antipyretic, and anti-inflammatory properties, and are thought to relieve pain by inhibiting cyclooxygenases and thus the production of prostaglandins (Hawkey 1999). Prostaglandins occur throughout body tissues and fluids and act to stimulate pain nerve endings and promote/inhibit the aggregation of blood platelets. Cyclo-oxygenase has at least two isoforms: COX-1 and COX-2. COX-1 is constitutive while COX-2 is induced at sites of inflammation and produces the prostaglandins involved in inflammatory responses and pain mediation (GrahameSmith 2002). Unlike traditional NSAIDs such as ibuprofen and ketoprofen, the coxibs are selective inhibitors, blocking primarily the action of COX-2, providing pain relief, and causing fewer gastrointestinal effects (Moore 2005b). In addition, they should not precipitate bleeding events through inhibition of platelet aggregation (Straube 2005). Etoricoxib is more highly selective of COX-2 over COX-1 than celecoxib.

In common with other NSAIDS, COX-2 inhibitors can give rise to fluid retention and renal damage (Garner 2002), so particular caution is needed in the elderly (Hawkey 2001). COX-2 inhibitors have been implicated in increased cardiovascular problems in longterm use, but this is complicated by differences in pharmacology and pharmacokinetics (Patrono 2009). Moreover, recent evidence indicates that prior cardiac damage may be a more important trigger than any particular drug or class of drug (Ruff 2011). 


\section{Why it is important to do this review}

Etoricoxib is one of a small group of COX-2 selective NSAIDs that provide pain relief with fewer gastrointestinal adverse events than traditional NSAIDs. This update is important because at licensed doses etoricoxib is one of the more effective and longest lasting analgesics in acute pain.

\section{OB JECTIVES}

To assess the efficacy and adverse effects of single-dose etoricoxib for acute postoperative pain using methods that permit accurate comparison with other analgesics evaluated in the same way, using criteria of efficacy recommended by in-depth studies at the individual patient level (Moore 2005a; Moore 2011b).

\section{METHODS}

\section{Criteria for considering studies for this review}

\section{Types of studies}

We included studies if they were full publications of double-blind studies of a single-dose oral etoricoxib against placebo for the treatment of moderate to severe postoperative pain in adults, with at least 10 participants randomly allocated to each treatment group. We included multiple-dose studies if appropriate data from the first dose were available, and we included cross-over studies provided that data from the first arm were presented separately.

We excluded studies if they were:

- posters or abstracts not followed up by full publication;

- reports of studies concerned with pain other than postoperative pain (including experimental pain);

- studies using volunteer participants;

- studies where pain relief was assessed by clinicians, nurses, or carers (i.e. not patient-reported); and

- studies of less than four hours' duration or that failed to present data over four to six hours post dose.

\section{Types of participants}

We included studies of adult participants (15 years old or more) with established postoperative pain of moderate to severe intensity following day surgery or in-patient surgery. For studies using a visual analogue scale (VAS), pain of at least moderate intensity was assumed when the VAS score was greater than $30 \mathrm{~mm}$ (Collins 1997). We included studies of participants with postpartum pain provided the pain investigated resulted from episiotomy or Caesarean section (with or without uterine cramp). We excluded studies investigating participants with pain due to uterine cramps alone.

\section{Types of interventions}

We included studies in which orally administered etoricoxib or matched placebo was given as a single dose for relief of postoperative pain.

\section{Types of outcome measures}

Data collected included the following:

- characteristics of participants;
- pain models;

- patient-reported pain at baseline (physician, nurse, or carer reported pain was not included in the analysis);

- patient-reported pain relief and pain intensity expressed hourly over four to six hours using validated pain scales (pain intensity and pain relief in the form of VAS or categorical scales, or both), or reported total pain relief (TOTPAR) or summed pain intensity difference (SPID) at four to six hours;

- patient-reported global assessment of treatment (PGE), using a validated scale;

- number of participants using rescue medication and the time of assessment;

- time to use of rescue medication;

- withdrawals - all causes and adverse events; and

- adverse events - participants experiencing one or more, and any serious adverse event, and the time of assessment.

\section{Primary outcomes}

Participants achieving at least $50 \%$ pain relief over four to six hours.

\section{Secondary outcomes}

1. Median (or mean) time to use of rescue medication.

2. Participants using rescue medication.

3. Participants with:

a. any adverse event;

b. any serious adverse event (as reported in the study); and

c. withdrawal due to an adverse event.

4. Withdrawals for reasons other than lack of efficacy (participants using rescue medication) and adverse events

\section{Search methods for identification of studies}

We applied no language restriction.

\section{Electronic searches}

We searched the following databases:

- the Cochrane Central Register of Controlled Trials (CENTRAL) (in The Cochrane Library Issue 1, 2014);

- MEDLINE (1996 to 31 January 2014);

- EMBASE (1980 to 31 January 2014);

- Oxford Pain Database (Jadad 1996a) for original review only; and

- www.clinicaltrials.gov (on 31 January 2014) for update only.

Details of the search strategies for MEDLINE are in Appendix 1, EMBASE in Appendix 2, and CENTRAL in Appendix 3.

We did not search online databases from inception because etoricoxib was not in clinical trials until around 2000. We ran searches for the original review up to December 2009, for the first update to 3 January 2012, and for this update to 31 January 2014.

\section{Searching other resources}

We searched reference lists of retrieved articles and reviews for additional studies. We did not search short abstracts, conference proceedings, and other grey literature, and we did not contact manufacturers. 


\section{Data collection and analysis}

\section{Selection of studies}

Two review authors independently assessed and agreed the search results for studies that might be included in the review. We resolved disagreements by consensus or referral to a third review author.

\section{Data extraction and management}

Two review authors independently extracted and recorded data on a standard data extraction form. One review author entered data suitable for pooling into Review Manager (RevMan) 5.1 (RevMan 2011).

\section{Assessment of risk of bias in included studies}

Two review authors independently assessed each study using a three-item, five-point scale (Jadad 1996b), and agreed a consensus score. We also completed a 'Risk of bias' table, considering randomisation, allocation concealment, blinding, incomplete outcome data, and size.

\section{Measures of treatment effect}

We used relative risk (or 'risk ratio', RR) to establish statistical difference. We used numbers needed to treat (NNT) and pooled percentages as absolute measures of benefit or harm.

We use the following terms to describe adverse outcomes in terms of harm or prevention of harm:

- When significantly fewer adverse outcomes occur with etoricoxib than with control (placebo or active) we use the term the number needed to treat to prevent one event (NNTp).

- When significantly more adverse outcomes occur with etoricoxib compared with control (placebo or active) we use the term the number needed to harm or cause one event (NNH).

\section{Unit of analysis issues}

We accepted only randomisation to the individual participant.

\section{Dealing with missing data}

The only likely issue with missing data in these studies is from imputation using last observation carried forward when a participant requests rescue medication. We have previously shown that this does not affect results for up to six hours after taking study medication (Barden 2004b).

\section{Assessment of heterogeneity}

We examined heterogeneity visually using L'Abbé plots (L'Abbé 1987).

\section{Data synthesis}

We followed QUOROM (Quality of Reporting of Meta-analyses) guidelines (Moher 1999). For efficacy analyses we used the number of participants in each treatment group who were randomised, received medication, and provided at least one postbaseline assessment. For safety analyses we used the number of participants randomised to each treatment group who took the study medication. We planned analyses for different doses. to \%maxTOTPAR or \%maxSPID by division into the calculated maximum value (Cooper 1991), and calculated the proportion of participants in each treatment group who achieved at least 50\%maxTOTPAR using verified equations (Moore 1996; Moore 1997a; Moore 1997b). We then converted these proportions into the number of participants achieving at least $50 \%$ maxTOTPAR by multiplying by the total number of participants in the treatment group. We used this information on the number of participants with at least 50\% maxTOTPAR for active and placebo to calculate relative benefit or relative risk, and number needed to treat to benefit (NNT).

We accepted the following pain measures for the calculation of TOTPAR or SPID:

- five-point categorical pain relief (PR) scales with comparable wording to 'none, slight, moderate, good or complete';

- four-point categorical pain intensity (PI) scales with comparable wording to 'none, mild, moderate, severe';

- VAS for pain relief; and

- VAS for pain intensity.

If none of these measures were available, we used the number of participants reporting 'very good or excellent' on a five-point categorical global scale with the wording 'poor, fair, good, very good, excellent' for the number of participants achieving at least $50 \%$ pain relief (Collins 2001).

For each treatment group we extracted the number of participants reporting treatment-emergent adverse effects and calculated relative benefit and risk estimates with 95\% confidence intervals (CI) using a fixed-effect model (Morris 1995). We calculated NNT and number needed to treat to harm $(\mathrm{NNH})$ and $95 \% \mathrm{Cl}$ using the pooled number of events using the method devised by Cook and Sackett (Cook 1995). We assumed a statistically significant difference from control when the $95 \% \mathrm{Cl}$ of the relative risk or relative benefit did not include the number one.

A minimum of two studies and 200 participants had to be available for reporting statistical analysis of pooled data.

\section{Subgroup analysis and investigation of heterogeneity}

We planned subgroup analyses to determine the effect of dose and presenting condition (pain model).

\section{Sensitivity analysis}

We planned sensitivity analyses for trial size (39 participants or fewer versus 40 or more per treatment arm) and quality score (two versus three or more).

A minimum of two studies and 200 participants had to be available in any subgroup or sensitivity analysis (Moore 1998), which were restricted to the primary outcome (50\% pain relief over four to six hours) and the dose with the greatest amount of data (120 mg). We determined significant differences between NNT, NNTp, or NNH for different groups in subgroup and sensitivity analyses using the $Z$ test (Tramèr 1997). 


\section{RESULTS}

\section{Description of studies}

Searches for the original review in 2009 (Clarke 2009) identified seven potentially relevant studies. Five of these studies fulfilled the inclusion criteria in 2009 (Chang 2004; Malmstrom 2004a; Malmstrom 2004b; Malmstrom 2005; Rasmussen 2005). We excluded one study after reading the full report, because it had no placebo group (Chalini 2005), and another as it was a press release (Anonymous 2001).

One further study was identified in the original review as ongoing and was subsequently published, and included in the 2012 update (Daniels 2011). One excluded study, previously available only as a summary in a clinical trials registry, has now been published (Viscusi 2012). We identified no new studies for this update (Figure $1)$. 
Figure 1. Study flow diagram.

$$
\begin{aligned}
& 9 \text { full text studies assessed for } \\
& \text { eligibility in original review in } \\
& 2009
\end{aligned}
$$

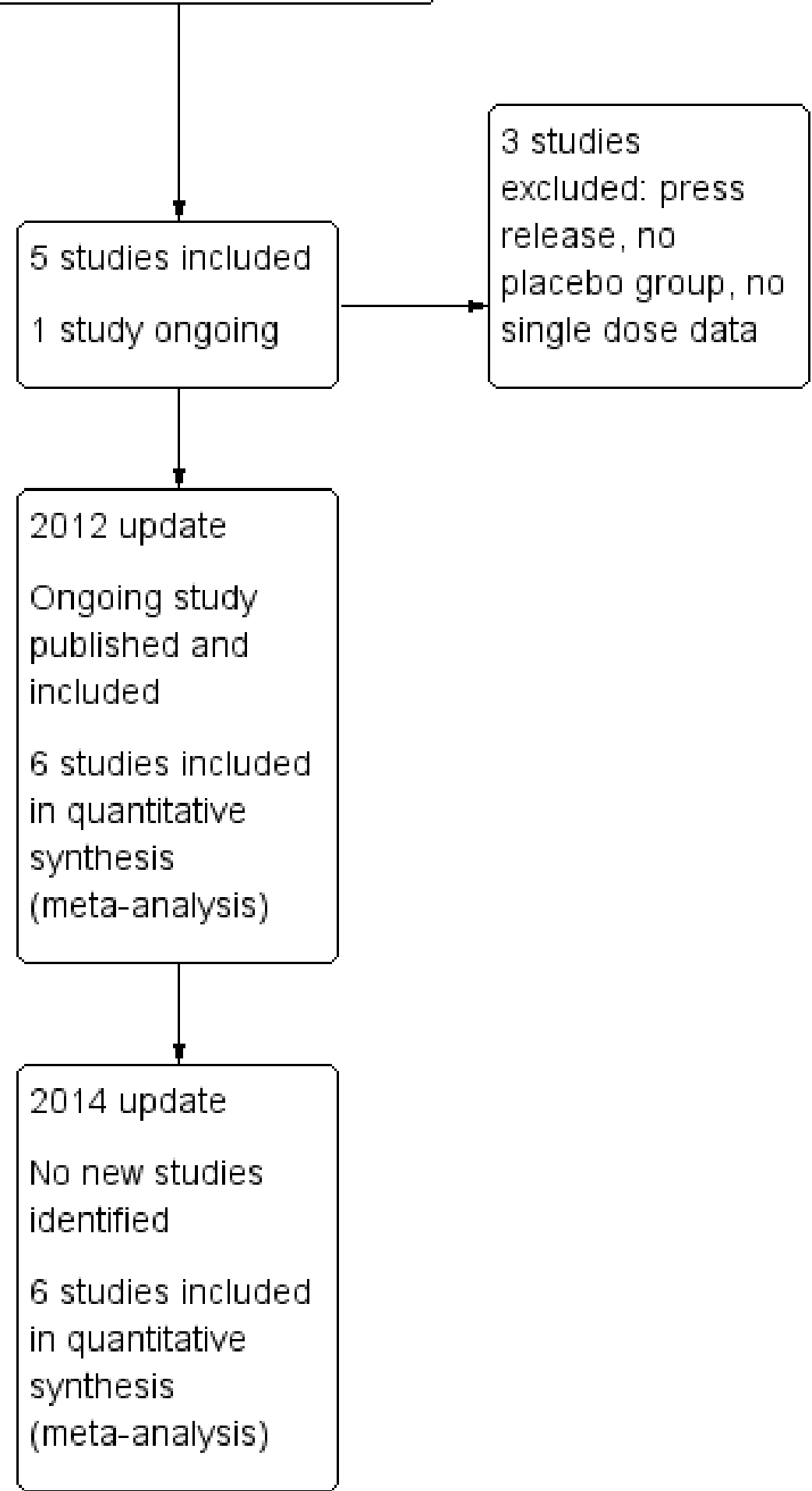


Details are in the 'Characteristics of included studies' and the 'Characteristics of excluded studies' tables.

In the included studies, a total of 919 participants were treated with different doses of etoricoxib and 295 with placebo; it was common in these studies for placebo group size to be smaller than active group size. In addition, 150 participants were treated with oxycodone/paracetamol (10/650 mg), 162 with codeine/ paracetamol (60/600 mg), 240 with ibuprofen (400 or $600 \mathrm{mg}$ ), and 73 with controlled-release naproxen sodium.

Six of the studies (Chang 2004; Daniels 2011; Malmstrom 2004a; Malmstrom 2004b; Malmstrom 2005; Rasmussen 2005), used etoricoxib $120 \mathrm{mg}$ in six treatment arms, etoricoxib $60 \mathrm{mg}$ in one treatment arm (Malmstrom 2004a), etoricoxib $90 \mathrm{mg}$ in one treatment arm (Daniels 2011), etoricoxib $180 \mathrm{mg}$ in one treatment arm (Malmstrom 2004a), and etoricoxib $240 \mathrm{mg}$ in one treatment arm (Malmstrom 2004a).

Five studies (Chang 2004; Daniels 2011; Malmstrom 2004a; Malmstrom 2004b; Malmstrom 2005) enrolled participants with dental pain following extraction of at least one impacted third molar, and one study (Rasmussen 2005) enrolled participants with pain following uncomplicated orthopaedic surgery.

Trial duration was 24 hours in five studies (Chang 2004; Daniels 2011; Malmstrom 2004a; Malmstrom 2004b; Malmstrom 2005), and 24 hours in the single-dose component of Rasmussen 2005. One study (Rasmussen 2005) included multiple doses, but reported results separately for the first dose (up to 24 hours) for at least some relevant outcomes. Another (Daniels 2011) used four doses over 24 hours, but only the first dose in the etoricoxib arms contained the active ingredient, and efficacy data are reported for the first dose separately.

\section{Risk of bias in included studies}

All included studies were both randomised and double-blind, and were given a quality score of four or five. Full details of the studies can be found in the 'Characteristics of included studies' tables.

We completed a 'Risk of bias' table for each study, with results presented graphically in Figure 2 and summarised in Figure 3. The major threat to reliability was the relatively small size of the studies.

Figure 2. 'Risk of bias' graph: review authors' judgements about each risk of bias item presented as percentages across all included studies.

Random sequence generation (selection bias)

Allocation concealment (selection bias)

Blinding (performance bias and detection bias)

Incomplete outcome data (attrition bias)

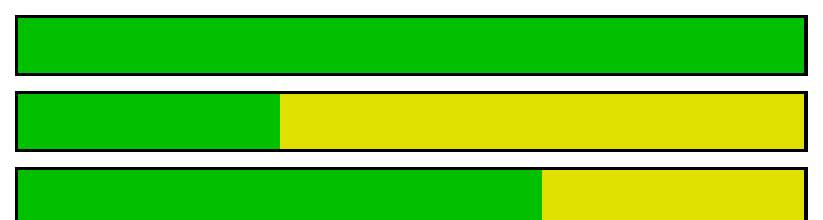

Other bias

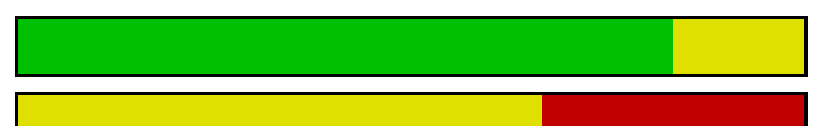

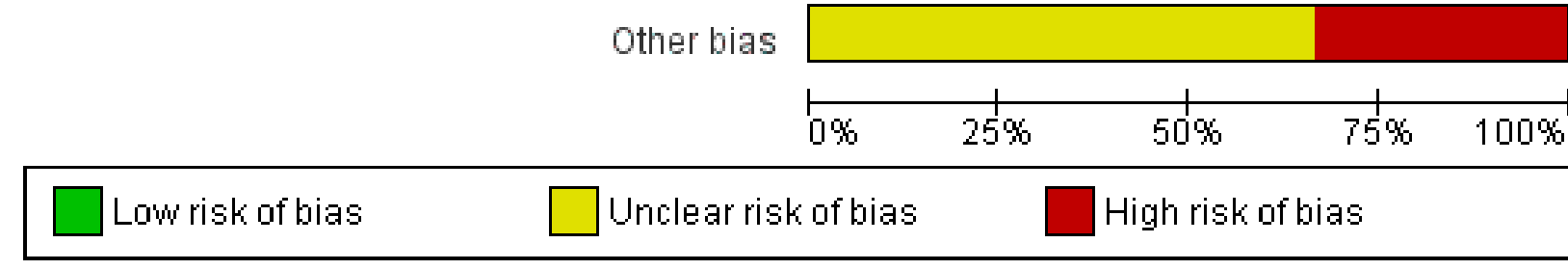


Figure 3. 'Risk of bias' summary: review authors' judgements about each risk of bias item for each included study.

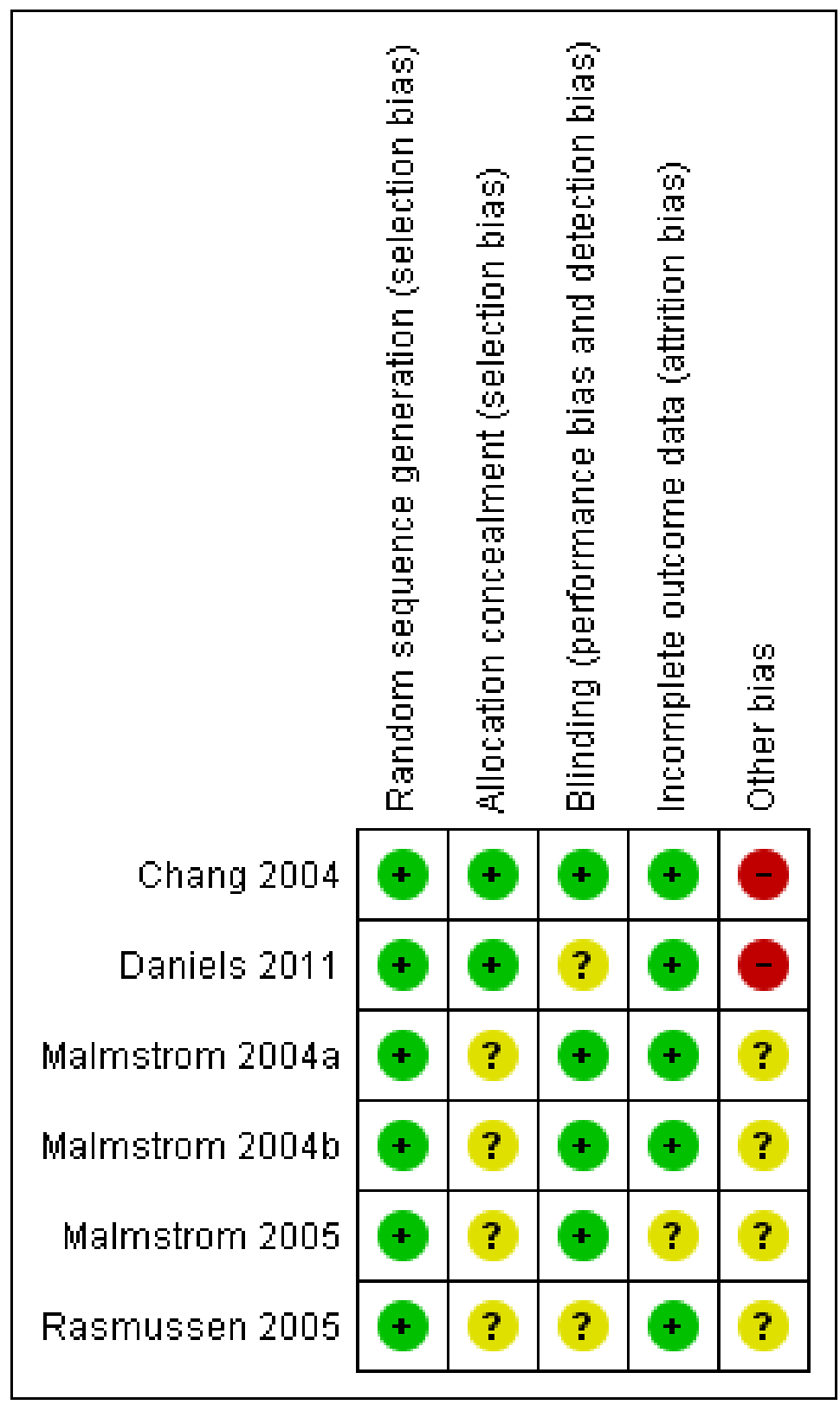

\section{Effects of interventions}

See: Summary of findings for the main comparison

All six included studies contributed data for quantitative analysis. Pooled analysis was possible only for the $120 \mathrm{mg}$ dose as only one treatment arm was available for each of the other doses. Details of the results of the individual studies can be seen in Appendix 5 (efficacy) and Appendix 6 (adverse events and withdrawals).

\section{Number of participants with at least $50 \%$ pain relief over four to six hours}

The 'Summary of results' table below shows all the results available, with relative risk (RR) and number needed to treat to benefit (NNT) calculated. However, data from more than one study were available only for the $120 \mathrm{mg}$ dose, and data with more than
200 participants in the comparison were available only for the 90 $\mathrm{mg}$ and $120 \mathrm{mg}$ doses. Etoricoxib $90 \mathrm{mg}$ may be a licensed dose for acute pain in some countries, so we performed calculations despite the limited participant numbers available from a single study.

\section{Etoricoxib $60 \mathrm{mg}$}

Data were available for only 75 participants treated with etoricoxib $60 \mathrm{mg}$, all with dental pain (Malmstrom 2004a). Of these, the proportion experiencing at least $50 \%$ pain relief over six hours was $59 \%(44 / 75)$ compared with $12 \%(6 / 49)$ with placebo.

\section{Etoricoxib $90 \mathrm{mg}$ versus placebo}

Data were available for 191 participants treated with etoricoxib 90 mg, all with dental pain (Daniels 2011). 
- The proportion of participants experiencing at least $50 \%$ pain relief over four to six hours with etoricoxib $90 \mathrm{mg}$ was $77 \%$ (148/191).

- The proportion of participants experiencing at least $50 \%$ pain relief over four to six hours with placebo was $17 \%(8 / 46)$.

- The relative benefit of treatment compared with placebo was 4.5 (2.4 to 8.4); the NNT was 1.7 (1.4 to 2.1).

\section{Etoricoxib $120 \mathrm{mg}$ versus placebo}

Six studies (798 participants) provided data for pain relief over six hours, with pain following dental or orthopaedic surgery
(Chang 2004; Daniels 2011; Malmstrom 2004a; Malmstrom 2004b; Malmstrom 2005; Rasmussen 2005).

- The proportion of participants experiencing at least $50 \%$ pain relief over four to six hours with etoricoxib $120 \mathrm{mg}$ was $66 \%$ (332/503).

- The proportion of participants experiencing at least $50 \%$ pain relief over four to six hours with placebo was $12 \%(34 / 295)$.

- The relative benefit of treatment compared with placebo was 5.6 (4.0 to 7.8); the NNT was 1.8 (1.7 to 2.0) (Analysis 1.1; Figure 4).

Figure 4. Forest plot of comparison: 1 Etoricoxib $120 \mathrm{mg}$ versus placebo, outcome: 1.1 Participants with at least $50 \%$ pain relief over 6 hours

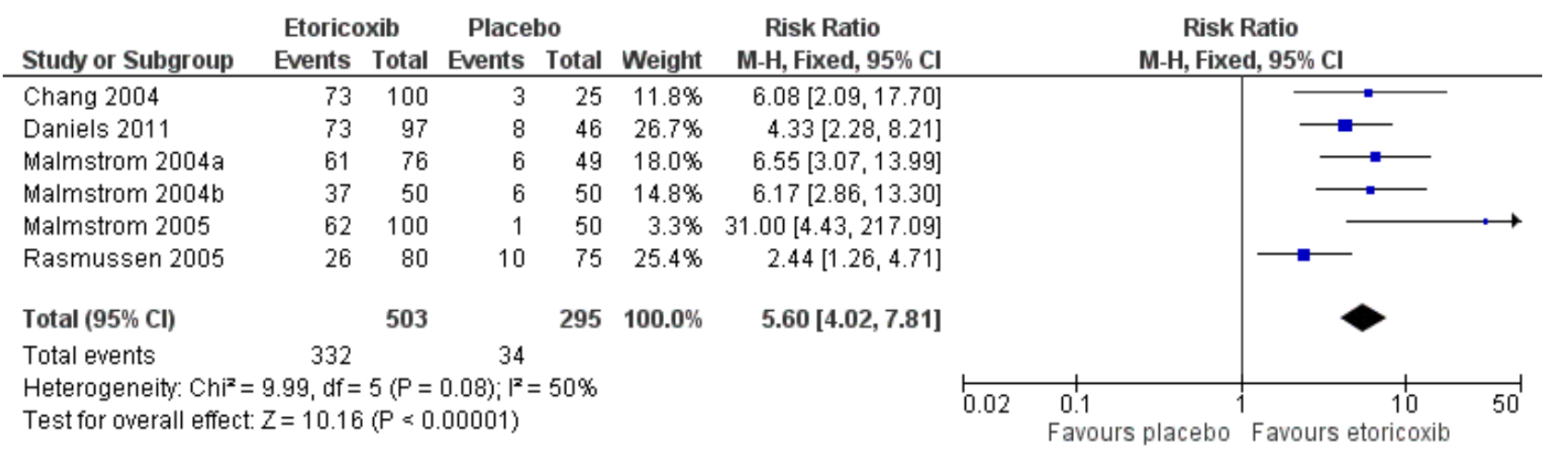

For dental studies only (five studies, 643 participants; Chang 2004; Daniels 2011; Malmstrom 2004a; Malmstrom 2004b; Malmstrom 2005), the relative benefit of treatment compared with placebo was
6.7 (4.6 to 9.8) and the NNT was 1.6 (1.5 to 1.8 ) (Analysis 1.2; Figure 5). 
Figure 5. L'Abbé plot of etoricoxib $120 \mathrm{mg}$ versus placebo for at least $50 \%$ pain relief. Size of circle is proportional to size of study (inset scale). Cream circles - dental studies; pink circle - orthopaedic study.

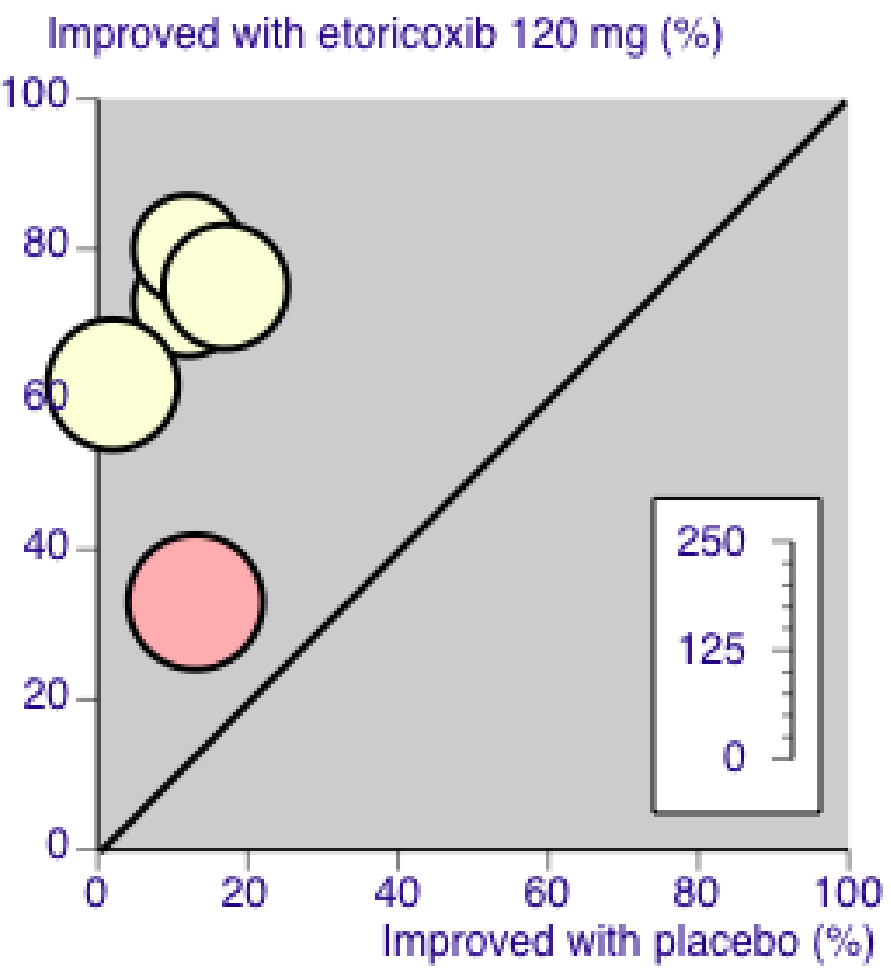

\section{Etoricoxib $180 \mathrm{mg}$ versus placebo}

Data were available for 75 participants treated with etoricoxib 180 $\mathrm{mg}$ (Malmstrom 2004a). Of these, the proportion experiencing at least $50 \%$ pain relief over six hours was $85 \%(64 / 74)$ compared with $12 \%(6 / 49)$ with placebo.

\section{Etoricoxib $240 \mathrm{mg}$ versus placebo}

Data were available for 76 participants treated with etoricoxib 240 $\mathrm{mg}$ (Malmstrom 2004a). Of these, the proportion experiencing at least $50 \%$ pain relief over six hours was $72 \%(55 / 76)$ compared with $12 \%(6 / 49)$ with placebo.

There was insufficient information to demonstrate a definitive dose response.

Summary of results: number of participants with $\geq 50 \%$ pain relief over 4 to 6 hours

\begin{tabular}{lllllll}
\hline Dose $(\mathbf{m g})$ & Studies & Participants & $\begin{array}{l}\text { Etoricoxib } \\
(\%)\end{array}$ & $\begin{array}{l}\text { Placebo } \\
(\%)\end{array}$ & RR (95\% CI) & NNT (95\%Cl) \\
\hline 60 & 1 & 124 (dental) & 59 & 12 & not calculated & not calculated \\
\hline 90 & 1 & 237 (dental) & 77 & 17 & $4.5(2.4$ to 8.4$)$ & $1.7(1.4$ to 2.1$)$ \\
\hline 120 & 6 & 798 & 66 & 12 & $5.6(4.0$ to 7.8$)$ & $1.8(1.7$ to 2.0$)$ \\
\hline 120 & 5 & 643 (dental only) & 72 & 11 & 6.7 (4.6 to 9.8) & $1.6(1.5$ to 1.8$)$ \\
\hline 180 & 1 & 123 (dental) & 86 & 12 & not calculated & not calculated \\
\hline 240 & 1 & 125 (dental) & 72 & 12 & not calculated & not calculated
\end{tabular}




\section{Sensitivity analyses of the primary outcome}

\section{Pain model}

Only one study (Rasmussen 2005) included participants who had undergone orthopaedic rather than dental surgery. There were insufficient data to compare results for dental and other surgery.

\section{Quality score}

All studies scored five for quality, so we did not carry out sensitivity analysis.

\section{Trial size}

All studies enrolled more than 40 participants per treatment arm, so we did not carry out sensitivity analysis.

\section{Proportion of participants using rescue medication}

All studies reported the proportion of participants using rescue medication for both etoricoxib and placebo, apart from Malmstrom 2005, in which omitted the placebo data (Appendix 5). We therefore excluded this study from this section of our analysis.

\section{Use of rescue medication over six hours}

Two studies (Chang 2004; Daniels 2011) reported use of rescue medication over six hours.
- For etoricoxib $90 \mathrm{mg} \mathrm{8.4 \%} \mathrm{(16/191)} \mathrm{required} \mathrm{rescue} \mathrm{medication,}$ compared with 65\% (30/46) with placebo.

- For etoricoxib $120 \mathrm{mg} 17 \%$ (34/197) required rescue medication, compared with $68 \%$ (48/71) with placebo. The relative benefit of treatment compared with placebo was 0.24 (0.17 to 0.34 ); the number needed to treat to prevent one event (NNTp) was 2.0 (1.6 to 2.6) (Analysis 1.3).

\section{Use of rescue medication over 24 hours}

Four studies (Chang 2004; Malmstrom 2004a; Malmstrom 2004b; Rasmussen 2005) reported use of rescue medication over 24 hours.

- For etoricoxib $60 \mathrm{mg} 52 \%$ (39/75) required rescue medication, compared with $82 \%$ (40/49) with placebo.

- For etoricoxib $120 \mathrm{mg} 50 \%(154 / 306)$ required rescue medication, compared with $89 \%$ (178/199) with placebo. The relative benefit of treatment compared with placebo was 0.60 (0.53 to 0.67); the NNTp was 2.6 (2.2 to 3.1) (Analysis 1.4; Figure 6). For dental studies only, the proportions were $39 \%(88 / 226)$ for etoricoxib and $84 \%(104 / 124)$ for placebo, giving a relative benefit of treatment compared with placebo of 0.46 ( 0.38 to 0.56 ), and NNTp of 2.2 (1.9 to 2.8 ).

- For etoricoxib $180 \mathrm{mg} 26 \%$ (19/74) required rescue medication, compared with $82 \%$ (40/49) with placebo.

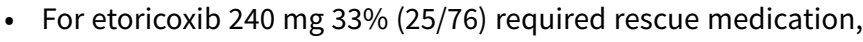
compared with $82 \%$ (40/49) with placebo.

Figure 6. Forest plot of comparison: 1 Etoricoxib $120 \mathrm{mg}$ vs placebo, outcome: 1.4 Participants using rescue medication within 24 hours

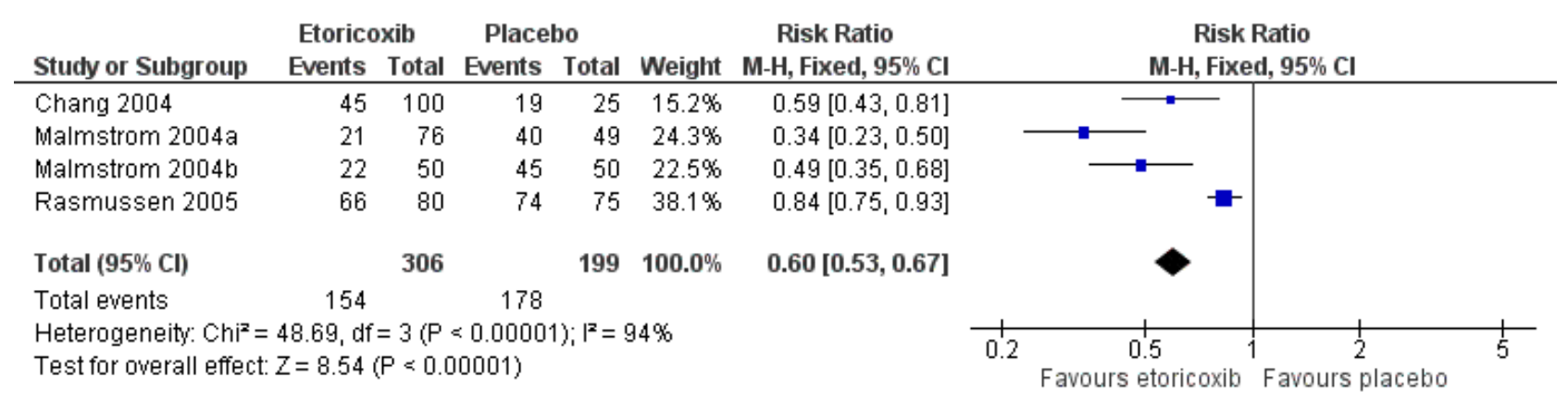

\section{Time to use of rescue medication}

For etoricoxib $120 \mathrm{mg}$ the median time to use of rescue medication exceeded 24 hours in all the dental studies, whereas for the orthopaedic study (Rasmussen 2005), it was 3.6 hours (Appendix 5). Daniels 2011 reported this outcome only at six hours, with all active treatment arms having less than 50\% remedication, while the median time to use of rescue medication was 2.1 hours with placebo. For the remaining dental and orthopaedic studies combined, the weighted mean of the median time to use of rescue medication was 20.0 hours for etoricoxib $120 \mathrm{mg}$ and 2.0 hours for placebo. For dental studies only, the weighted mean of the median time to use of rescue medication exceeded 24 hours.

\section{Adverse events}

All the dental studies (Chang 2004; Daniels 2011; Malmstrom 2004a; Malmstrom 2004b; Malmstrom 2005) reported the number of participants with one or more adverse event for each treatment arm, although the time over which the information was collected varied between trials, from six hours to 14 days. It was unclear in one study (Chang 2004) whether the adverse event reports covered the duration of the trial ( 24 hours), or whether they included any adverse events occurring between the end of the trial and a followup visit some days later. Rasmussen 2005, the orthopaedic study, did not provide any single dose data for adverse events (Appendix 6).

For all doses combined there was no significant difference in the proportion of participants experiencing at least one adverse event with etoricoxib $(32 \%, 272 / 839)$ and placebo $(36 \%, 79 / 220)$, giving a relative risk of 0.91 (0.74 to 1.1 ) (Analysis 2.1; Figure 7). There was again no significant difference for the $120 \mathrm{mg}$ dose alone, with $33 \%(140 / 423)$ experiencing adverse events with etoricoxib, and $36 \%(79 / 220)$ with placebo, giving a relative risk of $0.93(0.74$ to 1.2$)$ (Analysis 1.5). 
Figure 7. Forest plot of comparison: 2 Etoricoxib (all doses) versus placebo, outcome: 2.1 Participants with any adverse event

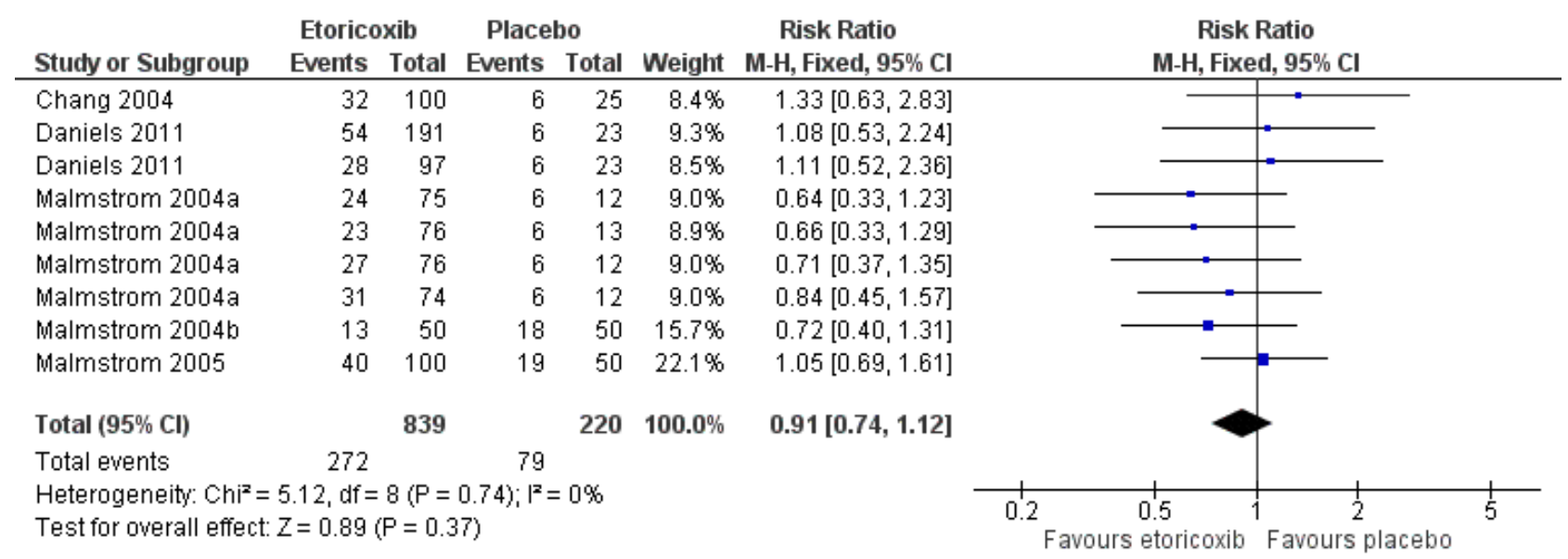

Adverse events were generally described as mild to moderate in severity. There were no serious adverse events reported for etoricoxib. One study (Malmstrom 2004b) reported one serious adverse event in the sodium naproxen $550 \mathrm{mg}$ treatment arm. This event, multiple fractures after a car accident, was reported 12 days after the study drug was taken and judged to be unrelated to the study medication.

\section{Withdrawals}

We classified participants who took rescue medication as withdrawals due to lack of efficacy, which we reported under 'Use of rescue medication' above. Withdrawals for reasons other than lack of efficacy were uncommon and usually due to protocol violations. No withdrawals due to adverse events were reported (Appendix 6).

\section{DISCUSSION}

\section{Summary of main results}

Six studies satisfied the inclusion criteria for this updated review, providing information for both efficacy and harm for doses of etoricoxib ranging from $60 \mathrm{mg}$ to $240 \mathrm{mg}$, although only the $120 \mathrm{mg}$ dose provided sufficient data for a pooled analysis of any outcome. Sixty-six per cent of those taking a single $120 \mathrm{mg}$ dose of etoricoxib experienced the clinically useful primary outcome of at least $50 \%$ pain relief, compared with about $12 \%$ of those taking placebo. The number needed to treat to benefit (NNT) for at least $50 \%$ pain relief was 1.8 (1.7 to 2.0), meaning that almost one in two participants treated with etoricoxib $120 \mathrm{mg}$ experienced this level of pain relief who would not have done so if treated with placebo. Limited data from one study in orthopaedic pain following initial patientcontrolled analgesia and appropriate washout, suggest that it is also effective in this situation, but less so. There were insufficient data to demonstrate a dose response.

Indirect comparisons of NNTs for at least 50\% pain relief over four to six hours in reviews of other analgesics using identical methods (Moore 2011a) indicate that etoricoxib $120 \mathrm{mg}$ has:

- equivalent efficacy to soluble ibuprofen $400 \mathrm{mg}$ (NNT 1.8 (1.7 to 2.0), naproxen 500/550 mg (NNT 1.8 (1.6 to 2.1)), and diclofenac potassium $100 \mathrm{mg}$ (NNT 1.9 (1.7 to 2.2 ));
- slightly better efficacy than standard ibuprofen $400 \mathrm{mg}$ (NNT 2.3 (2.2 to 2.5)) and celecoxib $400 \mathrm{mg}$ (NNT 2.5 (2.2 to 2.9)); and

- much better efficacy than aspirin $1000 \mathrm{mg}$ (NNT 4.2 (3.2 to 6.0)), diclofenac sodium $100 \mathrm{mg}$ (NNT 4.5 (3.2 to 7.6)), and paracetamol $1000 \mathrm{mg}$ (NNT 3.2 (2.9 to 3.6$)$ ).

It has been suggested that data on the use of rescue medication, whether as a proportion of participants requiring it or the median time to its use, might be helpful in assessing the usefulness of an analgesic, and possibly distinguishing between different doses (Moore 2005a). In this review only about half of participants treated with etoricoxib $120 \mathrm{mg}$ following dental surgery required rescue medication within 24 hours, compared to nearly all those treated with placebo. Indirect comparisons with other analgesics for duration of action (Moore 2011a) indicate that etoricoxib $120 \mathrm{mg}$ has a longer duration of action than celecoxib $400 \mathrm{mg}$ ( 8.4 hours) and commonly used traditional NSAIDs, such as ibuprofen $400 \mathrm{mg}$ (5.4 hours), diclofenac $100 \mathrm{mg}$ (4.9 hours), and naproxen $500 \mathrm{mg}$ ( 8.9 hours). Longer duration of action may be advantageous in some circumstances. In a postoperative setting, where patients may feel nauseated, a longer time before remedication is needed may be of benefit to the patient, and it may also reduce demands on time for nursing staff. There were insufficient data to examine the effect of dose on duration of action.

Reporting of data for adverse events, withdrawals (other than lack of efficacy), or exclusions, and handling of missing data was better in these recent studies than in many older reports of single-dose analgesics. Poor reporting of adverse events in acute pain trials has been noted before (Edwards 1999). The method of reporting adverse events (usually specified as 'spontaneous') was not explicit (e.g. patient diary, recall at follow-up visit) and they were collected over different periods of time. This almost certainly included periods after the use of rescue medication, which may cause its own adverse events. The usefulness of single dose studies for assessing adverse events is questionable, but it is nonetheless reassuring that in these studies there was no difference between etoricoxib (at any dose) and placebo for occurrence of any adverse event, and there were no serious adverse events or adverse event withdrawals. Long-term, multiple-dose studies should be used for meaningful analysis of adverse events since, even in acute pain settings, analgesics are likely to be used in multiple doses. 


\section{Overall completeness and applicability of evidence}

Included studies reported useful data for both primary and secondary outcomes, with the exception of placebo results for time to use of rescue medication in Malmstrom 2005. Five studies were carried out in participants with pain following surgical removal of impacted third molars. These individuals were generally in their early 20s and otherwise fit and healthy, so are clearly not representative of the range of individuals who might need analgesia for acute postoperative pain. There is no a priori reason why analgesic response in these individuals should differ in any systematic way from a more generalised population, but it is entirely possible that adverse events (gastrointestinal in particular) may be more frequent, intense, or severe in older patients and those with comorbidities. The remaining study was carried out in patients with pain following orthopaedic surgery, and while response with placebo was the same as in dental pain, response with etoricoxib was lower in this one study. This may be due to chance, greater age of participants (mean 65 years), or a fundamental difference in the painful condition. Differences between different pain models have either not been demonstrable in the past (Barden 2004c) or have been possible to demonstrate only where there is an abundance of data (e.g. for ibuprofen; Derry 2009c).

Data for doses other than $120 \mathrm{mg}$ were limited to one treatment arm each, so we could not make inferences about benefit and harm of lower and higher doses.

\section{Quality of the evidence}

All studies were of high methodological quality, scoring $4 / 5$ or $5 / 5$ on the Oxford Quality Scale, and all administered the medication when pain levels were moderate or severe, ensuring that the study was sensitive to detect a $50 \%$ reduction.

We judged two studies to be at high risk of bias because the placebo arms were small (<50 participants), despite moderate numbers (100 to 200) in the active treatment arms (Chang 2004; Daniels 2011). There were no other major concerns about potential bias in individual studies.

\section{Potential biases in the review process}

We carried out a comprehensive search for relevant studies and investigated the potential influence of publication bias by examining the number of participants in studies with zero effect (relative risk of 1.0) needed for the point estimate of the NNT to increase beyond a clinically useful level (Moore 2008). In this case, we chose a clinically useful level as eight. For the primary outcome of at least $50 \%$ pain relief with etoricoxib $120 \mathrm{mg}$, more than 5000 participants would have to have been involved in unpublished trials with zero treatment effects for the NNT to increase above this threshold. It is highly unlikely that this amount of missing data exists.

\section{Agreements and disagreements with other studies or reviews}

We are not aware of any other reviews of etoricoxib to treat acute postoperative pain.

\section{AUTHORS' CONCLUSIONS}

\section{Implications for practice}

A single dose of etoricoxib $120 \mathrm{mg}$ (and probably $90 \mathrm{mg}$ ) is an effective analgesic, providing at least $50 \%$ pain relief to about two-thirds of treated patients with acute, moderate to severe, postoperative pain (high-quality evidence). The number needed to treat to benefit (NNT) of 1.8 for at least $50 \%$ pain relief and median time to use of rescue medication of more than 20 hours are both better than other analgesics commonly used for postoperative pain. In a single dose it is associated with a low rate of mainly mild adverse events, similar to that with placebo.

\section{Implications for research}

We identified no new studies for this update. It is unlikely that further studies will be carried out for this dose and in this setting, and if they were, that they would change the result here. Studies at lower doses might help to determine whether lower doses can provide adequate analgesia without loss of duration of action. Multiple-dose studies over a longer duration may help to evaluate the risk of adverse events, particularly rare adverse events (serious, death), and more adequately reflect clinical practice. However, such information is more likely to be taken from studies in chronic pain, such as arthritis.

It is more important to recognise the gulf between results in singledose clinical trials and in treatment of acute pain in clinical practice. Single-dose trials can show that certain drugs at certain doses produce excellent analgesia in the majority of patients. Surveys consistently show that acute pain is badly treated, even in hospital, and that a large percentage of patients suffer moderate or severe pain over long periods. The clinical practice research agenda is how best to use the excellent analgesics we have to improve day-to-day results in treatment of acute pain in hospital and primary care.

\section{ACKNOWLEDGEMENTS}

The Oxford Pain Relief Trust supported both updates. The NHS Cochrane Collaboration Programme Grant Scheme supported the original review.

Jodie Barden and Jayne Rees developed the protocol and ran preliminary searches for the first version of this review, and Henry McQuay was an author. 


\section{REFERE N C E S}

\section{References to studies included in this review}

Chang 2004 \{published data only\}

Chang DJ, Desjardins PJ, King TR, Erb T, Geba GP. The analgesic efficacy of etoricoxib compared with oxycodone/acetaminophen in an acute postoperative pain model: a randomized, double-blind clinical trial. Anesthesia and Analgesia 2004;99(3):807-15. [DOI: 10.1213/01.ANE.0000133141.75831.57]

\section{Daniels 2011 \{published data only\}}

Daniels SE, Bandy DP, Christensen SE, Boice J, Losada MC, $\mathrm{Liu} \mathrm{H}$, et al. Evaluation of the dose range of etoricoxib in an acute pain setting using the postoperative dental pain model. Clinical Journal of Pain 2011;27(1):1-8. [DOI: 10.1097/ AJP.0b013e3181ed0639]

\section{Malmstrom 2004a \{published data only\}}

Malmstrom K, Sapre A, Couglin H, Agrawal NG, Mazenko RS, Fricke JR Jr. Etoricoxib in acute pain associated with dental surgery: a randomized, double-blind, placeboand active comparator-controlled dose-ranging study. Clinical Therapeutics 2004;26(5):667-79. [DOI: 10.1016/ S0149-2918(04)90067-7]

\section{Malmstrom 2004b \{published data only\}}

Malmstrom K, Kotey P, Coughlin H, Desjardins PJ. A randomized, double-blind, parallel-group study comparing the analgesic effect of etoricoxib to placebo, naproxen sodium, and acetaminophen with codeine using the dental impaction pain model. Clinical Journal of Pain 2004;20(3):147-55.

\section{Malmstrom 2005 \{published data only\}}

Malmstrom K, Ang J, Fricke JR, Shingo S, Reicin A. The analgesic effect of etoricoxib relative to that of cetaminophen analgesics: a randomized, controlled single-dose study in acute dental impaction pain. Current Medical Research and Opinion 2005;21(1):141-9. [DOI: 10.1185/030079904X17983]

\section{Rasmussen 2005 \{published data only\}}

Rasmussen GL, Malmstrom K, Bourne MH, Jove M, Rhondeau SM, Kotey P. Etoricoxib provides analgesic efficacy to patients after knee or hip replacement surgery: a randomized, double-blind, placebo-controlled study. Anesthesia and Analgesia 2005;101(4):1104-11. [DOI: 10.1213/01.ane.0000169294.41210.9e]

\section{References to studies excluded from this review}

\section{Anonymous 2001 \{published data only\}}

Anonymous. Investigational COX-2 inhibitor relieves pain in a dental model. Current Pain and Headache Reports 2001;11(8):1059-62.

\section{Chalini 2005 \{published data only\}}

Chalini S, Raman U. Comparative efficacy of aceclofenac and etoricoxib in post extraction pain control: randomized control trial. Indian Journal of Dental Research 2005;16(2):47-50.
Viscusi 2012 \{published and unpublished data\}

A double-blind, placebo-controlled, multicenter trial to study the efficacy and tolerability of MK0663/Etoricoxib in the treatment of pain after abdominal hysterectomy. www.ClinicalTrials.gov (accessed 31 January 2014).

[ClinicalTrials.gov ID: NCT00788710]

* Viscusi ER, Frenkl TL, Hartrick CT, Rawal N, Kehlet H, Papanicolaou D, et al. A double-blind, placebo-controlled, multicenter trial to study the efficacy and tolerability of MK0663/Etoricoxib in the treatment of pain after abdominal hysterectomy. Current Medical Research and Opiniion 2012;28(8):1323-5. [DOI: 10.1185/03007995.2012.707121]

\section{Additional references}

\section{Barden 2004a}

Barden J, Edwards JE, McQuay HJ, Wiffen PJ, Moore RA. Relative efficacy of oral analgesics after third molar extraction. British Dental Journal 2004;197(7):407-11.

\section{Barden 2004b}

Barden J, Edwards JE, Mason L, McQuay HJ, Moore RA. Outcomes in acute pain trials: systematic review of what was reported?. Pain 2004;109(3):351-6. [DOI: 10.1016/ j.pain.2004.01.032]

\section{Barden 2004c}

Barden J, Edwards JE, McQuay HJ, Andrew Moore R. Pain and analgesic response after third molar extraction and other postsurgical pain. Pain 2004;107(1-2):86-90. [DOI: 10.1016/ j.pain.2003.09.021]

\section{Collins 1997}

Collins SL, Moore RA, McQuay HJ. The visual analogue pain intensity scale: what is moderate pain in millimetres?. Pain 1997;72:95-7.

\section{Collins 2001}

Collins SL, Edwards J, Moore RA, Smith LA, McQuay HJ. Seeking a simple measure of analgesia for mega-trials: is a single global assessment good enough?. Pain 2001;91:189-94.

\section{Cook 1995}

Cook RJ, Sackett DL. The number needed to treat: a clinically useful measure of treatment effect. BMJ 1995;310:452-4.

\section{Cooper 1991}

Cooper SA. Single-dose analgesic studies: the upside and downside of assay sensitivity. In: Max MB, Portenoy RK, Laska EM editor(s). The Design of Analgesic Clinical Trials. Advances in Pain Research and Therapy. Vol. 18, New York: Raven Press, 1991:117-24.

\section{Derry 2009a}

Derry C, Derry S, Moore RA, McQuay HJ. Single dose oral naproxen and naproxen sodium for acute postoperative pain in 
adults. Cochrane Database of Systematic Reviews 2009, Issue 1. [DOI: 10.1002/14651858.CD004234.pub3]

\section{Derry 2009b}

Derry P, Derry S, Moore RA, McQuay HJ. Single dose oral diclofenac for acute postoperative pain in adults. Cochrane Database of Systematic Reviews 2009, Issue 2. [DOI: 10.1002/14651858.CD004768]

\section{Derry 2009c}

Derry C, Derry S, Moore RA, McQuay HJ. Single dose oral ibuprofen for acute postoperative pain in adults. Cochrane Database of Systematic Reviews 2009, Issue 3. [DOI: 10.1002/14651858.CD001548.pub2]

\section{Derry 2011}

Derry S, Wiffen PJ, Moore RA. Relative efficacy of oral analgesics after third molar extraction - a 2011 update. British Dental Journal 2011;211(9):419-20. [DOI: 10.1038/sj.bdj.2011.905]

\section{Derry 2013}

Derry S, Moore RA. Single dose oral celecoxib for acute postoperative pain in adults. Cochrane Database of Systematic Reviews 2013, Issue 10. [DOI: 10.1002/14651858.CD004233.pub4]

\section{Edwards 1999}

Edwards JE, McQuay HJ, Moore RA, Collins SL. Reporting of adverse effects in clinical trials should be improved: lessons from acute postoperative pain. Journal of Pain and Symptom Management 1999;18(6):427-37. [DOI: 10.1016/ S0885-3924(99)00093-7]

\section{Garner 2002}

Garner S, Fidan D, Frankish R, Judd M, Towheed T, Wells G. Rofecoxib for the treatment of rheumatoid arthritis. Cochrane Database of Systematic Reviews 2002, Issue 2. [DOI: 10.1002/14651858.CD003685]

\section{Grahame-Smith 2002}

Grahame-Smith DG, Aronson JK. Oxford Textbook of Clinical Pharmacology and Drug Therapy. 3rd Edition. Oxford: Oxford University Press, 2002.

\section{Hawkey 1999}

Hawkey CJ. COX-2 inhibitors. Lancet 1999;353(9149):307-14.

\section{Hawkey 2001}

Hawkey CJ, Jones JI. Gastrointestinal safety of COX-2 specific inhibitors. Gastroenterology Clinics of North America 2001;30(4):921-36.

\section{Jadad 1996a}

Jadad AR, Carroll D, Moore A, McQuay H. Developing a database of published reports of randomised clinical trials in pain research. Pain 1996;66(2-3):239-46. [DOI: 10.1016/0304-3959(96)03033-3]

\section{Jadad 1996b}

Jadad AR, Moore RA, Carroll D, Jenkinson C, Reynolds DJM, Gavaghan DJ, et al. Assessing the quality of reports of randomized clinical trials: is blinding necessary?. Controlled Clinical Trials 1996;17:1-12. [DOI: 10.1016/0197-2456(95)00134-4]

\section{L'Abbé 1987}

L'Abbé KA, Detsky AS, O'Rourke K. Meta-analysis in clinical research. Annals of Internal Medicine 1987;107:224-33.

\section{McQuay 2005}

McQuay HJ, Moore RA. Placebo. Postgraduate Medical Journal 2005;81:155-60.

\section{Moher 1999}

Moher D, Cook DJ, Eastwood S, Olkin I, Rennie D, Stroup DF. Improving the quality of meta-analyses of randomised controlled trials: the QUOROM statement. Lancet 1999;354:1896-900. [DOI: 10.1016/S0140-6736(99)04149-5]

\section{Moore 1996}

Moore A, McQuay H, Gavaghan D. Deriving dichotomous outcome measures from continuous data in randomised controlled trials of analgesics. Pain 1996;66(2-3):229-37.

\section{Moore 1997a}

Moore A, McQuay H, Gavaghan D. Deriving dichotomous outcome measures from continuous data in randomised controlled trials of analgesics: verification from independent data. Pain 1997;69(1-2):127-30.

\section{Moore 1997b}

Moore A, Moore O, McQuay H, Gavaghan D. Deriving dichotomous outcome measures from continuous data in randomised controlled trials of analgesics: use of pain intensity and visual analogue scales. Pain 1997;69(3):311-5.

\section{Moore 1998}

Moore RA, Gavaghan D, Tramer MR, Collins SL, McQuay HJ. Size is everything-large amounts of information are needed to overcome random effects in estimating direction and magnitude of treatment effects. Pain 1998;78(3):209-16. [DOI: 10.1016/S0304-3959(98)00140-7]

\section{Moore 2003}

Moore RA, Edwards JE, Barden J, McQuay HJ. Bandolier's Little Book of Pain. Oxford: Oxford University Press, 2003. [ISBN: 0-19-263247-7]

\section{Moore 2005a}

Moore RA, Edwards JE, McQuay HJ. Acute pain: individual patient meta-analysis shows the impact of different ways of analysing and presenting results. Pain 2005;116(3):322-31. [DOI: 10.1016/j.pain.2005.05.001]

\section{Moore 2005b}

Moore RA, Derry S, Makinson GT, McQuay HJ. Tolerability and adverse events in clinical trials of celecoxib in osteoarthritis and rheumatoid arthritis: systematic review and meta-analysis of information from company clinical trial reports. Arthritis Research \& Therapy 2005;7(3):R644-65. [DOI: 10.1186/ar1704] 


\section{Moore 2006}

Moore A, McQuay H. Bandolier's Little Book of Making Sense of the Medical Evidence. Oxford: Oxford University Press, 2006. [ISBN: 0-19-856604-2]

\section{Moore 2008}

Moore RA, Barden J, Derry S, McQuay HJ. Managing potential publication bias. In: McQuay HJ, Kalso E, Moore RA editor(s). Systematic Reviews in Pain Research: Methodology Refined. Seattle: IASP Press, 2008:15-24. [ISBN: 978-0-931092-69-5]

\section{Moore 2011a}

Moore RA, Derry S, McQuay HJ, Wiffen PJ. Single dose oral analgesics for acute postoperative pain in adults. Cochrane Database of Systematic Reviews 2011, Issue 9. [DOI: 10.1002/14651858.CD008659.pub2]

\section{Moore 2011b}

Moore RA, Straube S, Paine J, Derry S, McQuay HJ. Minimum efficacy criteria for comparisons between treatments using individual patient meta-analysis of acute pain trials: examples of etoricoxib, paracetamol, ibuprofen, and ibuprofen/ paracetamol combinations after third molar extraction. Pain 2011;152(5):982-9. [DOI: doi:10.1016/j.pain.2010.11.030]

\section{Morris 1995}

Morris JA, Gardner MJ. Calculating confidence intervals for relative risk, odds ratio and standardised ratios and rates. In: Gardner MJ, Altman DG editor(s). Statistics with Confidence Confidence Intervals and Statistical Guidelines. London: British Medical Journal, 1995:50-63.

\section{PACT 2013}

Prescription Cost Analysis, England 2012. NHS Health and Social Care Information Centre 2013. [ISBN: 978-1-84-636859-2]

\section{Patrono 2009}

Patrono C, Baigent C. Low-dose aspirin, coxibs, and other NSAIDS: a clinical mosaic emerges. Molecular Interventions 2009;9(1):31-9.

\section{RevMan 2011 [Computer program]}

The Nordic Cochrane Centre, The Cochrane Collaboration. Review Manager (RevMan). Version 5.1. Copenhagen: The Nordic Cochrane Centre, The Cochrane Collaboration, 2011.

\section{CHARACTERISTICS OF STUDIES}

Characteristics of included studies [ordered by study ID]

\section{Roy 2010}

Roy YM, Derry S, Moore RA. Single dose oral lumiracoxib for postoperative pain in adults. Cochrane Database of Systematic Reviews 2010, Issue 7. [DOI: 10.1002/14651858.CD006865.pub2]

\section{Ruff 2011}

Ruff CT, Morrow DA, Jarolim P, Ren F, Contant CF, Kaur A, et al. Evaluation of NT-proBNP and high sensitivity C-reactive protein for predicting cardiovascular risk in patients with arthritis taking longterm nonsteroidal antiinflammatory drugs. Journal of Rheumatology 2011;38(6):1071-8. [DOI: 10.3899/ jrheum.100880]

\section{Straube 2005}

Straube S, Derry S, McQuay HJ, Moore RA. Effect of preoperative Cox-II-selective NSAIDs (coxibs) on postoperative outcomes: a systematic review of randomized studies. Acta Anaesthesiologica Scandinavica 2005;49(5):601-13. [DOI: 10.1111/j.1399-6576.2005.00666.x]

\section{Toms 2008}

Toms L, McQuay HJ, Derry S, Moore RA. Single dose oral paracetamol (acetaminophen) for postoperative pain in adults. Cochrane Database of Systematic Reviews 2008, Issue 4. [DOI: 10.1002/14651858.CD004602]

\section{Tramèr 1997}

Tramèr MR, Reynolds DJM, Moore RA, McQuay HJ. Impact of covert duplicate results on meta-analysis: a case study. BMJ 1997;315(7109):635-40.

\section{References to other published versions of this review \\ Clarke 2009}

Clarke R, Derry S, Moore RA, McQuay HJ. Single dose oral etoricoxib for acute postoperative pain in adults. Cochrane Database of Systematic Reviews 2009, Issue 2. [DOI: 10.1002/14651858.CD004309.pub2]

\section{Clarke 2012}

Clarke R, Derry S, Moore RA. Single dose oral etoricoxib for acute postoperative pain in adults. Cochrane Database of Systematic Reviews 2012, Issue 4. [DOI: 10.1002/14651858.CD004309.pub3]

* Indicates the major publication for the study

Chang 2004

Methods RCT, DB single oral dose, 3 parallel groups

Medication administered when baseline pain reached a moderate to severe intensity

Pain assessed at $0,15,30,45,60,90$ mins, then hourly up to 6 hours and at 12 and 24 hours

Participants Impacted third molar extraction


Chang 2004 (Continued)

$$
\begin{aligned}
& N=225 \\
& M=90, F=135
\end{aligned}
$$

Mean age 22 years

\begin{tabular}{ll}
\hline Interventions & Etoricoxib $120 \mathrm{mg}, \mathrm{n}=100$ \\
& Paracetamol $650 \mathrm{mg}+$ oxycodone $10 \mathrm{mg}, \mathrm{n}=100$ \\
& Placebo, $\mathrm{n}=25$
\end{tabular}

Pl: standard 4-point scale
PR: standard 5-point scale
PGE: standard 5-point scale
Time to use of rescue medication
Number of participants using rescue medication
Number of participants reporting adverse events and serious adverse events
Withdrawals

Notes

Oxford Quality Score: R2, DB2, W1

Participants asked to refrain from using rescue medication for 90 mins

\begin{tabular}{|c|c|c|}
\hline Bias & Authors' judgement & Support for judgement \\
\hline $\begin{array}{l}\text { Random sequence genera- } \\
\text { tion (selection bias) }\end{array}$ & Low risk & "computer-generated allocation schedule" \\
\hline $\begin{array}{l}\text { Allocation concealment } \\
\text { (selection bias) }\end{array}$ & Low risk & $\begin{array}{l}\text { Medication provided in labelled bottles, labelled A and B; separate sealed en- } \\
\text { velopes contained code in event of serious adverse event }\end{array}$ \\
\hline $\begin{array}{l}\text { Blinding (performance } \\
\text { bias and detection bias) } \\
\text { All outcomes }\end{array}$ & Low risk & "exact matching placebo" \\
\hline $\begin{array}{l}\text { Incomplete outcome data } \\
\text { (attrition bias) } \\
\text { All outcomes }\end{array}$ & Low risk & Participants accounted for; analysis appropriate for relevant time interval \\
\hline Other bias & High risk & Small treatment group size (100 active, 25 placebo participants) \\
\hline
\end{tabular}

\section{Risk of bias}

\section{Daniels 2011}

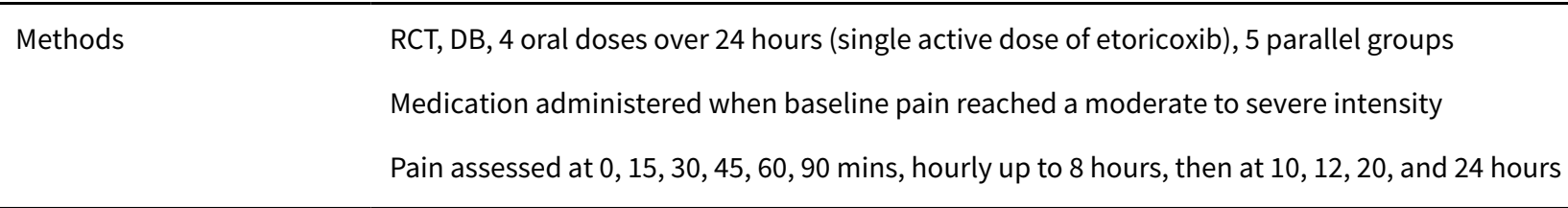


Daniels 2011 (Continued)

$$
\begin{aligned}
& N=588 \\
& M=248, F=340 \\
& \text { Mean age } 22 \text { years }
\end{aligned}
$$

\begin{tabular}{ll}
\hline Interventions & Etoricoxib $90 \mathrm{mg}, \mathrm{n}=191$ \\
& Etoricoxib $120 \mathrm{mg}, \mathrm{n}=97$ \\
& lbuprofen $600 \mathrm{mg}$ (6-hourly), $\mathrm{n}=192$ \\
& Paracetamol + codeine $600 / 60 \mathrm{mg}$ (6-hourly), $\mathrm{n}=62$ \\
& Placebo, $\mathrm{n}=46$
\end{tabular}

Pl: standard 4-point scale
PR: standard 5-point scale
PGE: standard 5-point scale
Time to use of rescue medication
Number of participants using rescue medication
Number of participants reporting adverse events and serious adverse events
Withdrawals

Notes Oxford Quality Score: R2, DB1, W1

Rescue medication available for inadequate response (no details of timing)

\section{Risk of bias}

\begin{tabular}{lll}
\hline Bias & Authors' judgement & Support for judgement \\
\hline $\begin{array}{l}\text { Random sequence genera- } \\
\text { tion (selection bias) }\end{array}$ & Low risk & Computer-generated \\
\hline $\begin{array}{l}\text { Allocation concealment } \\
\text { (selection bias) }\end{array}$ & Low risk & $\begin{array}{l}\text { Medication provided in numbered containers; participant allocated to next } \\
\text { number in sequence }\end{array}$ \\
\hline $\begin{array}{l}\text { Blinding (performance } \\
\text { bias and detection bias) } \\
\text { All outcomes }\end{array}$ & Unclear risk & $\begin{array}{l}\text { "in house blinding conditions". "Investigator, study nurse, patients, monitors, } \\
\text { laboratory personnel remained blinded throughout the study". }\end{array}$ \\
\hline $\begin{array}{l}\text { Incomplete outcome data } \\
\text { (attrition bias) } \\
\text { All outcomes }\end{array}$ & Low risk & \begin{tabular}{l} 
Participants accounted for; analysis appropriate for relevant time interval \\
\hline \begin{tabular}{l} 
Other bias \\
\hline
\end{tabular}
\end{tabular} \\
\hline
\end{tabular}

Malmstrom 2004a

\begin{tabular}{ll}
\hline Methods & RCT, DB, single oral dose, 6 parallel groups \\
& Medication administered when baseline pain reached a moderate to severe intensity \\
& Pain assessed at $0,15,30,45,60,90$ mins then at $2,3,4,5,6,7,8,12$, and 24 hours \\
\hline Participants & Impacted third molar extraction
\end{tabular}


Malmstrom 2004a (Continued)

$$
\begin{aligned}
& N=398 \\
& M=147, F=251
\end{aligned}
$$

Mean age 21 years

\begin{tabular}{ll}
\hline Interventions & Etoricoxib $60 \mathrm{mg}, \mathrm{n}=75$ \\
& Etoricoxib $120 \mathrm{mg}, \mathrm{n}=76$ \\
& Etoricoxib $180 \mathrm{mg}, \mathrm{n}=74$ \\
& Etoricoxib $240 \mathrm{mg}, \mathrm{n}=76$ \\
& Ibuprofen $400 \mathrm{mg}, \mathrm{n}=48$ \\
& Placebo, $\mathrm{n}=49$
\end{tabular}

PI: standard 4-point scale
PR: standard 5-point scale
PGE: standard 5-point scale
Time to use of rescue medication
Number of participants using rescue medication
Number of participants reporting adverse events and serious adverse events
Withdrawals

Notes Oxford Quality Score: R2, DB2, W1

Participants asked to refrain from using rescue medication for 90 mins

\section{Risk of bias}

\begin{tabular}{lll}
\hline Bias & Authors' judgement & Support for judgement \\
\hline $\begin{array}{l}\text { Random sequence genera- } \\
\text { tion (selection bias) }\end{array}$ & Low risk & "computer-generated allocation schedule" \\
\hline $\begin{array}{l}\text { Allocation concealment } \\
\text { (selection bias) }\end{array}$ & Unclear risk & Not described \\
\hline $\begin{array}{l}\text { Blinding (performance } \\
\text { bias and detection bias) } \\
\text { All outcomes }\end{array}$ & Low risk & Double-dummy method. "matching placebo tablet" for both active treatments \\
\hline $\begin{array}{l}\text { Incomplete outcome data } \\
\text { (attrition bias) } \\
\text { All outcomes }\end{array}$ & Low risk & Participants accounted for; analysis appropriate for relevant time interval \\
\hline $\begin{array}{l}\text { Other bias } \\
\end{array}$ & Unclear risk & Small treatment group size (48 to 76 participants) \\
\hline
\end{tabular}

Malmstrom 2004b

Methods $\quad$ RCT, DB, single oral dose, 4 parallel groups


Malmstrom 2004b (Continued)

Medication administered when baseline pain reached a moderate to severe intensity

Pain assessed at $0,15,30,45,60,90,120$ mins, then hourly to 8 hours, then at $10,12,20$, and 24 hours

\begin{tabular}{|c|c|c|}
\hline \multirow[t]{4}{*}{ Participants } & \multicolumn{2}{|c|}{ Impacted third molar extraction } \\
\hline & \multicolumn{2}{|l|}{$N=201$} \\
\hline & \multicolumn{2}{|l|}{$M=97, F=104$} \\
\hline & \multicolumn{2}{|l|}{ Mean age 23 years } \\
\hline \multirow[t]{4}{*}{ Interventions } & \multicolumn{2}{|c|}{ Etoricoxib $120 \mathrm{mg}, \mathrm{n}=50$} \\
\hline & \multicolumn{2}{|c|}{ Naproxen sodium $550 \mathrm{mg}, \mathrm{n}=51$} \\
\hline & \multicolumn{2}{|c|}{ Codeine $60 \mathrm{mg}$ + paracetamol $600 \mathrm{mg}, \mathrm{n}=50$} \\
\hline & \multicolumn{2}{|l|}{ Placebo, $n=50$} \\
\hline \multirow[t]{7}{*}{ Outcomes } & \multicolumn{2}{|c|}{ PI: standard 4-point scale } \\
\hline & \multicolumn{2}{|c|}{ PR: standard 5-point scale } \\
\hline & \multicolumn{2}{|c|}{ PGE: standard 5-point scale } \\
\hline & \multicolumn{2}{|c|}{ Time to use of rescue medication } \\
\hline & \multicolumn{2}{|c|}{ Number of participants using rescue medication } \\
\hline & \multicolumn{2}{|c|}{ Number of participants reporting adverse events and serious adverse events } \\
\hline & \multicolumn{2}{|l|}{ Withdrawals } \\
\hline Notes & \multirow{2}{*}{\multicolumn{2}{|c|}{$\begin{array}{l}\text { Oxford Quality Score: R2, DB2, W1 } \\
\text { Participants asked to refrain from using rescue medication for } 90 \text { mins }\end{array}$}} \\
\hline & & \\
\hline \multicolumn{3}{|l|}{ Risk of bias } \\
\hline Bias & Authors' judgement & Support for judgement \\
\hline $\begin{array}{l}\text { Random sequence genera- } \\
\text { tion (selection bias) }\end{array}$ & Low risk & Computer-generated allocation \\
\hline $\begin{array}{l}\text { Allocation concealment } \\
\text { (selection bias) }\end{array}$ & Unclear risk & Not described \\
\hline $\begin{array}{l}\text { Blinding (performance } \\
\text { bias and detection bias) } \\
\text { All outcomes }\end{array}$ & Low risk & Double-dummy method. "matching" placebo for each active treatment \\
\hline $\begin{array}{l}\text { Incomplete outcome data } \\
\text { (attrition bias) } \\
\text { All outcomes }\end{array}$ & Low risk & Participants accounted for; analysis appropriate for relevant time interval \\
\hline Other bias & Unclear risk & Small treatment group size (50 or 51 participants) \\
\hline
\end{tabular}


Malmstrom 2005

\begin{tabular}{ll}
\hline Methods & RCT, DB, single oral dose, 4 parallel groups \\
& Medication administered when baseline pain reached a moderate to severe intensity \\
& Pain assessed at $0,15,30,45,60,90,120$ mins, then hourly to 8 hours, then at $10,12,20$, and 24 hours \\
\hline Participants & Impacted third molar extraction \\
& $\mathrm{N}=302$ \\
& $\mathrm{M}=112, \mathrm{~F}=190$ \\
& Mean age 23 years \\
\hline Interventions & Etoricoxib $120 \mathrm{mg}, \mathrm{n}=100$ \\
Oxycodone $10 \mathrm{mg}+$ paracetamol $650 \mathrm{mg}, \mathrm{n}=102$ \\
Codeine $60 \mathrm{mg}+$ paracetamol $600 \mathrm{mg}, \mathrm{n}=50$ \\
Placebo, $\mathrm{n}=50$
\end{tabular}

Pl: standard 4-point scale
PR: standard 5-point scale
PGE: standard 5-point scale
Time to use of rescue medication
Number of participants using rescue medication
Number of participants reporting adverse events and serious adverse events
Withdrawals

Notes

Oxford Quality Score: R2, DB2, W1

Participants asked to refrain from using rescue medication for 90 mins

\section{Risk of bias}

\begin{tabular}{lll}
\hline Bias & Authors' judgement & Support for judgement \\
\hline $\begin{array}{l}\text { Random sequence genera- } \\
\text { tion (selection bias) }\end{array}$ & Low risk & "computer-generated allocation schedule" \\
\hline $\begin{array}{l}\text { Allocation concealment } \\
\text { (selection bias) }\end{array}$ & Unclear risk & Not described \\
\hline $\begin{array}{l}\text { Blinding (performance } \\
\text { bias and detection bias) } \\
\text { All outcomes }\end{array}$ & Low risk & "matching placebo tablets" \\
\hline $\begin{array}{l}\text { Incomplete outcome data } \\
\text { (attrition bias) } \\
\text { All outcomes }\end{array}$ & Unclear risk & Participants accounted for; analysis appropriate for relevant time interval \\
\hline $\begin{array}{l}\text { Other bias } \\
\end{array}$ & Unclear risk & Small treatment group size (50 to 102 participants) \\
\hline
\end{tabular}


Rasmussen 2005

\begin{tabular}{|c|c|}
\hline Methods & $\begin{array}{l}\text { RCT, DB, single and multiple oral doses, } 3 \text { parallel groups } \\
\text { Medication administered when baseline pain reached a moderate to severe intensity, after withdrawal } \\
\text { of patient controlled analgesia. } \\
\text { Patient assessment at } 0,30,60,90,120 \text { mins, then hourly to } 8 \text { hours, then at } 10,12,20 \text {, and } 24 \text { hours for } \\
\text { the single-dose study }\end{array}$ \\
\hline Participants & $\begin{array}{l}\text { Orthopaedic surgery ( } 40 \% \text { hip, } 60 \% \text { knee }) \\
N=228 \\
M=90, F=138 \\
\text { Mean age } 65 \text { years }\end{array}$ \\
\hline Interventions & $\begin{array}{l}\text { Etoricoxib } 120 \mathrm{mg}, \mathrm{n}=80 \\
\text { Naproxen sodium (CR) } 1100 \mathrm{mg}, \mathrm{n}=73 \\
\text { Placebo, } \mathrm{n}=75\end{array}$ \\
\hline Outcomes & $\begin{array}{l}\text { PR: standard 5-point scale } \\
\text { PGE: standard 5-point scale } \\
\text { Time to use of rescue medication } \\
\text { Number of participants using rescue medication } \\
\text { Number of participants reporting adverse events and serious adverse events } \\
\text { Withdrawals }\end{array}$ \\
\hline
\end{tabular}

\section{Notes}

Oxford Quality Score: R2, DB2, W1

Participants asked to refrain from using rescue medication for 90 mins

\section{Risk of bias}

\begin{tabular}{lll}
\hline Bias & Authors' judgement & Support for judgement \\
\hline $\begin{array}{l}\text { Random sequence genera- } \\
\text { tion (selection bias) }\end{array}$ & Low risk & "computer-generated allocation schedule" \\
\hline $\begin{array}{l}\text { Allocation concealment } \\
\text { (selection bias) }\end{array}$ & Unclear risk & Not described \\
\hline $\begin{array}{l}\text { Blinding (performance } \\
\text { bias and detection bias) } \\
\text { All outcomes }\end{array}$ & Unclear risk & Double-dummy method. "matching placebo tablet" for both active treatments \\
\hline $\begin{array}{l}\text { Incomplete outcome data } \\
\text { (attrition bias) } \\
\text { All outcomes }\end{array}$ & Low risk & Participants accounted for; analysis appropriate for relevant time interval \\
\hline $\begin{array}{l}\text { Other bias } \\
\end{array}$ & Unclear risk & Small treatment group size (73 to 80 participants) \\
\hline
\end{tabular}

DB - double-blind; F - female; M - male; $\mathrm{N}$ - total number in trial; $\mathrm{n}$ - number in treatment arm; PI - pain intensity; PR - pain relief; PGE patient global evaluation; R - randomised; RCT - randomised controlled trial; W - withdrawals 
Characteristics of excluded studies [ordered by study ID]

\begin{tabular}{ll}
\hline Study & Reason for exclusion \\
\hline Anonymous 2001 & Press release \\
\hline Chalini 2005 & No placebo group \\
\hline Viscusi 2012 & No single dose data. Unclear when medication was given - probably pre-emptive \\
\hline
\end{tabular}

\section{DATA AND ANALYSES}

Comparison 1. Etoricoxib 120 mg vs placebo

\begin{tabular}{|c|c|c|c|c|}
\hline Outcome or subgroup title & No. of studies & $\begin{array}{l}\text { No. of partici- } \\
\text { pants }\end{array}$ & Statistical method & Effect size \\
\hline $\begin{array}{l}1 \text { Participants with at least } 50 \% \text { pain relief } \\
\text { over } 6 \text { hours }\end{array}$ & 6 & 798 & $\begin{array}{l}\text { Risk Ratio (M-H, Fixed, } \\
95 \% \mathrm{Cl})\end{array}$ & $5.60[4.02,7.81]$ \\
\hline $\begin{array}{l}2 \text { Participants with at least } 50 \% \text { pain relief } \\
\text { over } 6 \text { hours, dental }\end{array}$ & 5 & 643 & $\begin{array}{l}\text { Risk Ratio (M-H, Fixed, } \\
95 \% \mathrm{Cl})\end{array}$ & $6.68[4.55,9.82]$ \\
\hline $\begin{array}{l}3 \text { Participants using rescue medication } \\
\text { within } 6 \text { hours }\end{array}$ & 2 & 268 & $\begin{array}{l}\text { Risk Ratio (M-H, Fixed, } \\
95 \% \mathrm{Cl})\end{array}$ & $0.24[0.17,0.34]$ \\
\hline $\begin{array}{l}4 \text { Participants using rescue medication } \\
\text { within } 24 \text { hours }\end{array}$ & 4 & 505 & $\begin{array}{l}\text { Risk Ratio (M-H, Fixed, } \\
95 \% \mathrm{Cl})\end{array}$ & $0.60[0.53,0.67]$ \\
\hline 5 Participants with any adverse event & 5 & 643 & $\begin{array}{l}\text { Risk Ratio (M-H, Fixed, } \\
95 \% \mathrm{Cl})\end{array}$ & $0.93[0.74,1.17]$ \\
\hline
\end{tabular}

Analysis 1.1. Comparison 1 Etoricoxib $120 \mathrm{mg}$ vs placebo, Outcome 1 Participants with at least 50\% pain relief over 6 hours.

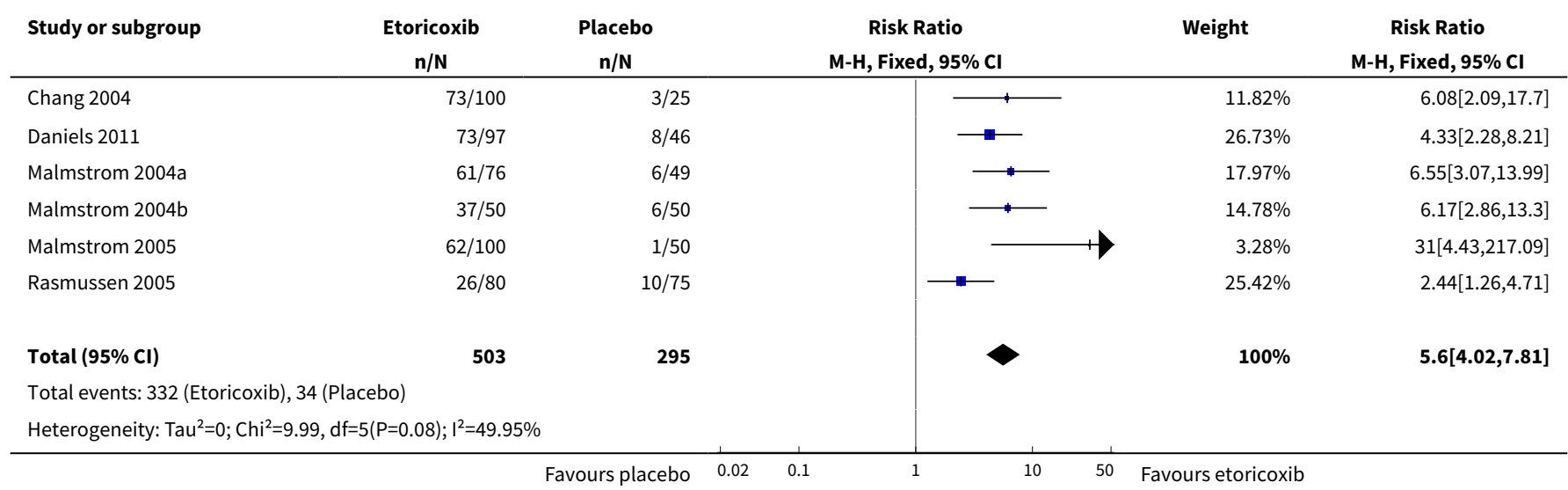




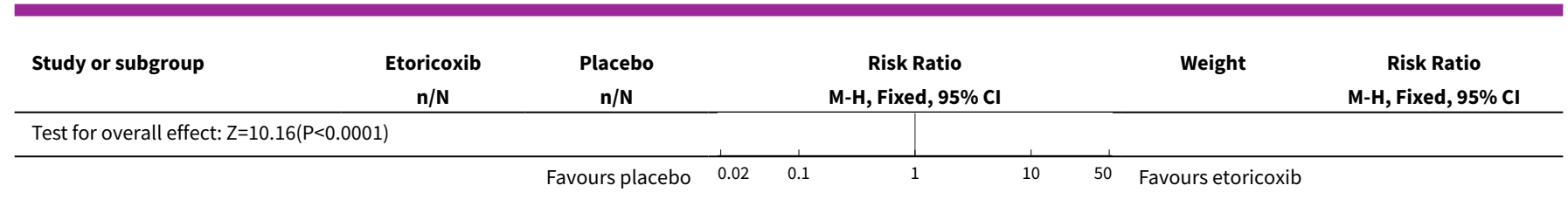

Analysis 1.2. Comparison 1 Etoricoxib 120 mg vs placebo, Outcome

2 Participants with at least $50 \%$ pain relief over 6 hours, dental.

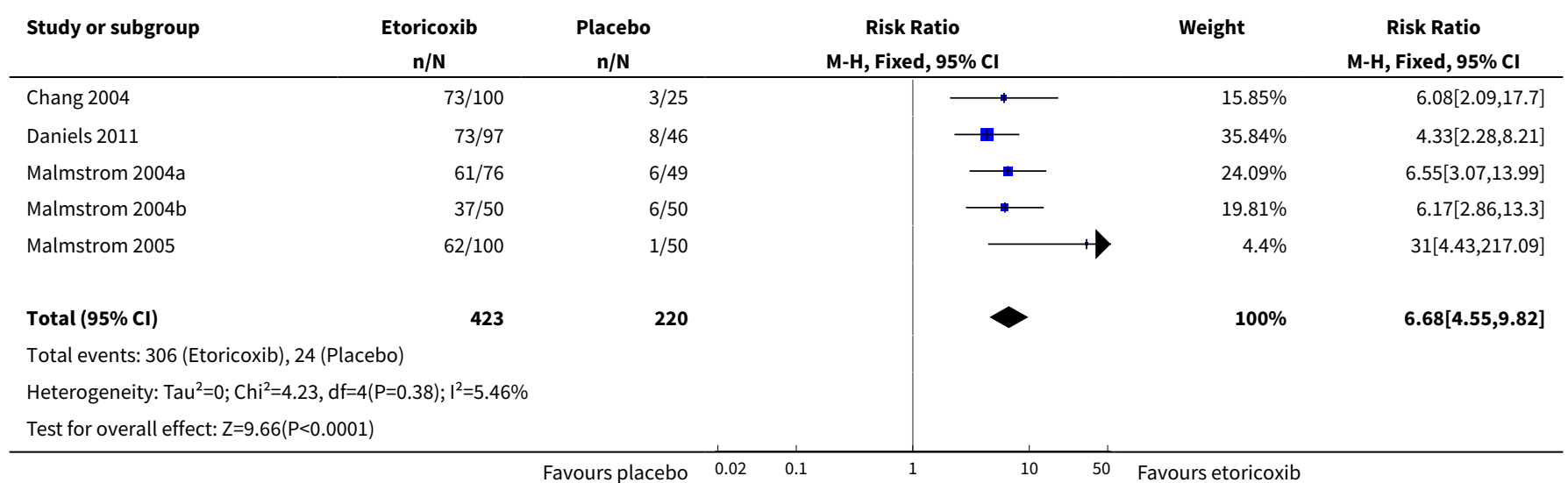

Analysis 1.3. Comparison 1 Etoricoxib $120 \mathrm{mg}$ vs placebo, Outcome 3 Participants using rescue medication within 6 hours.

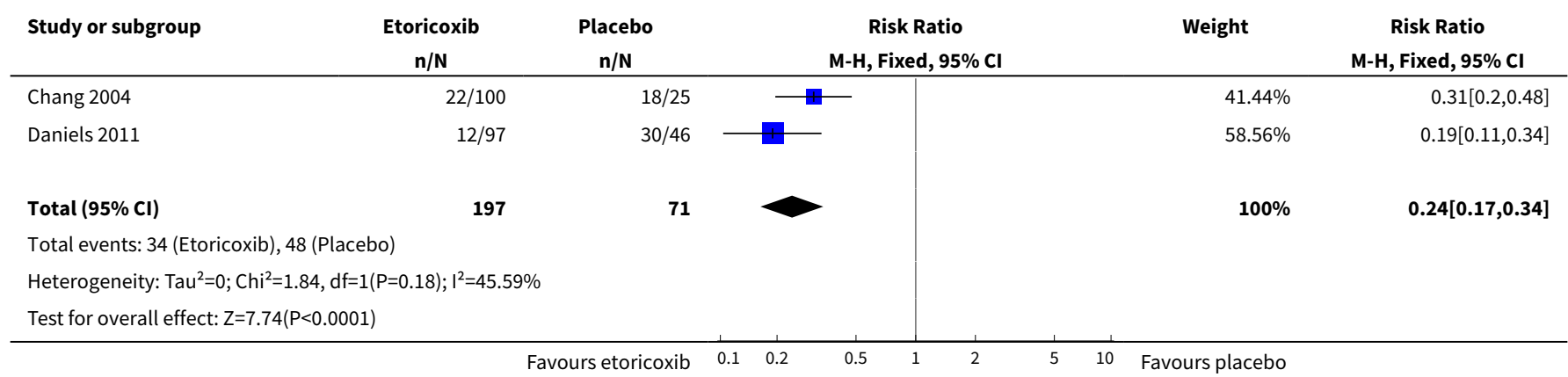

Analysis 1.4. Comparison 1 Etoricoxib $120 \mathrm{mg}$ vs placebo, Outcome 4 Participants using rescue medication within 24 hours.

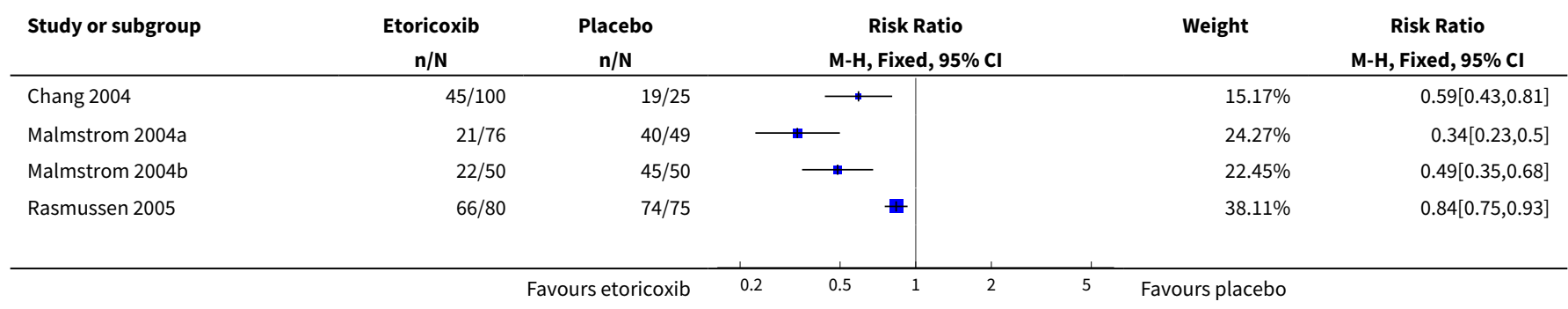




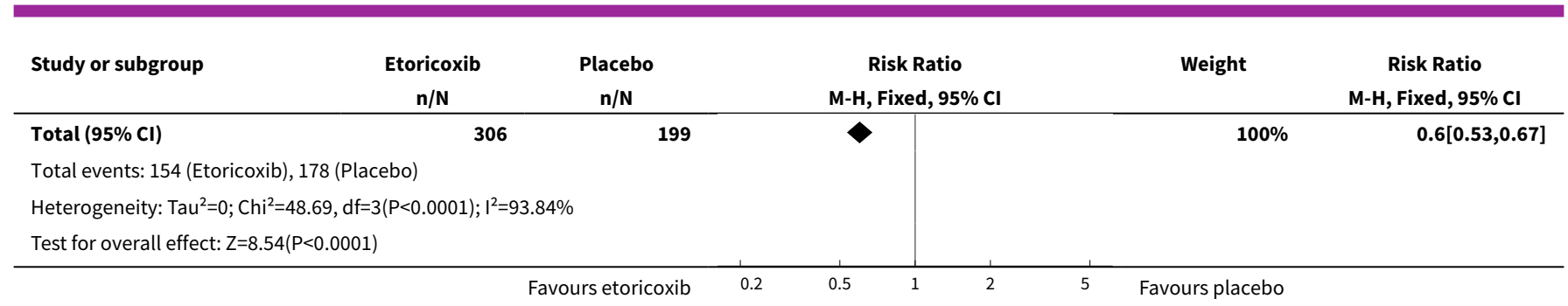

Analysis 1.5. Comparison 1 Etoricoxib 120 mg vs placebo, Outcome 5 Participants with any adverse event.

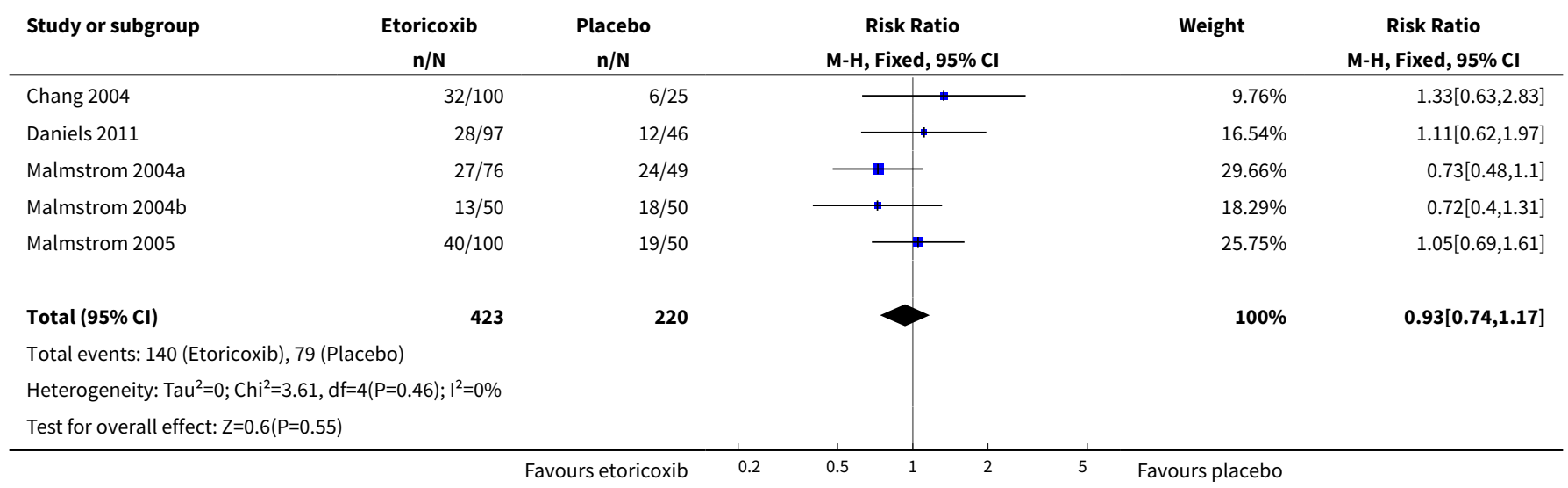

\section{Comparison 2. Etoricoxib (all doses) versus placebo}

\begin{tabular}{lllll}
\hline Outcome or subgroup title & No. of studies & $\begin{array}{l}\text { No. of partici- } \\
\text { pants }\end{array}$ & Statistical method & Effect size \\
\hline 1 Participants with any adverse event & 5 & 1059 & $\begin{array}{l}\text { Risk Ratio (M-H, Fixed, 95\% } \\
\text { Cl) }\end{array}$ & $0.91[0.74,1.12]$ \\
\hline
\end{tabular}

Analysis 2.1. Comparison 2 Etoricoxib (all doses) versus placebo, Outcome 1 Participants with any adverse event.

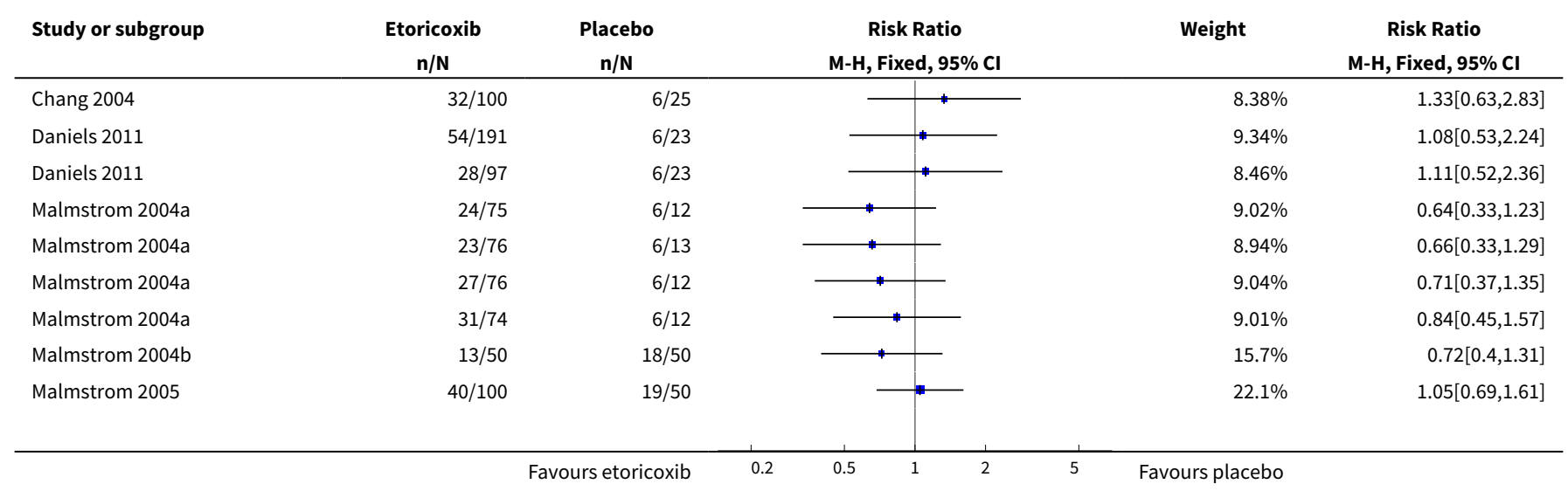




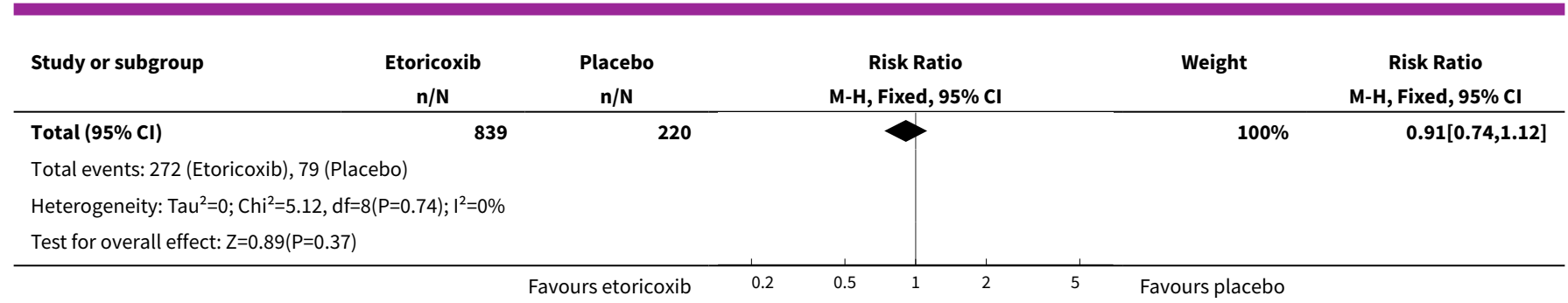

\section{APPENDICES}

\section{Appendix 1. MEDLINE via Ovid search strategy}

1. Etoricoxib.sh.

2. (etoricoxib OR arcoxia).ti.ab.kw.

3. 1 OR 2

4. Pain, Postoperative.sh.

5. ((postoperative adj4 pain\$) or (post-operative adj4 pain\$) or post-operative-pain\$ or (post\$ NEAR pain\$) or (postoperative adj4 analgesi \$) or (post-operative adj4 analgesi\$) or ("post-operative analgesi\$")).ti.ab.kw.

6. ((post-surgical adj4 pain\$) or ("post surgical" adj4 pain\$) or (post-surgery adj4 pain\$)).ti.ab.kw.

7. (("pain-relief after surg\$") or ("pain following surg\$") or ("pain control after")).ti.ab.kw.

8. (("post surg\$" or post-surg\$) AND (pain\$ or discomfort)).ti.ab.kw.

9. ((pain\$ adj4 "after surg\$") or (pain\$ adj4 "after operat\$") or (pain\$ adj4 "follow\$ operat\$") or (pain\$ adj4 "follow\$ surg\$")).ti.ab.kw.

10.((analgesi\$ adj4 "after surg\$") or (analgesi\$ adj4 "after operat\$") or (analgesi\$ adj4 "follow\$ operat\$") or (analgesi adj4 "follow\$ surg \$")).ti.ab.kw.

\section{$11.0 \mathrm{OR} / 4-10$}

12.randomized controlled trial.pt.

13.controlled clinical trial.pt.

14.randomized.ab.

15. placebo.ab.

16.drug therapy.fs.

17.randomly.ab.

18.trial.ab.

19.groups.ab.

20.0R/12-19

21.humans.sh.

22.20 AND 21

23.3 AND 11 AND 22

\section{Appendix 2. Search strategy for EMBASE via Ovid}

1. Etoricoxib.sh.

2. (etoricoxib OR arcoxia).ti,ab,kw.

3. $\mathrm{OR} / 1-2$

4. Postoperative pain.sh.

5. ((postoperative adj4 pain\$) or (post-operative adj4 pain\$) or post-operative-pain\$ or (post\$ NEAR pain\$) or (postoperative adj4 analgesi \$) or (post-operative adj4 analgesi\$) or ("post-operative analgesi\$")).ti.ab.kw.

6. ((post-surgical adj4 pain\$) or ("post surgical" adj4 pain\$) or (post-surgery adj4 pain\$)).ti.ab.kw.

7. (("pain-relief after surg\$") or ("pain following surg\$") or ("pain control after")).ti.ab.kw.

8. (("post surg\$" or post-surg\$) AND (pain\$ or discomfort)).ti.ab.kw.

9. ((pain\$ adj4 "after surg\$") or (pain\$ adj4 "after operat\$") or (pain\$ adj4 "follow\$ operat\$") or (pain\$ adj4 "follow\$ surg\$")).ti.ab.kw.

10.((analgesi\$ adj4 "after surg\$") or (analgesi\$ adj4 "after operat\$") or (analgesi\$ adj4 "follow\$ operat\$") or (analgesi\$ adj4 "follow\$ surg \$")).ti.ab.kw. 
11.OR/4-10

12. Clinical trials.sh.

13. Controlled Clinical Trials.sh.

14. Randomized Controlled Trial.sh.

15. Double-blind procedure.sh.

16. (clin\$ adj25 trial\$).ab.

17. ((doubl\$ or trebl\$ or tripl\$) adj25 (blind\$ or mask\$)).ab.

18.placebo\$.ab.

19.random\$.ab.

20.0R/12-19

21.3 AND 11 AND 20

\section{Appendix 3. Search strategy for Cochrane CENTRAL}

1. MESH descriptor Etoricoxib

2. (etoricoxib OR arcoxia):ti,ab,kw.

3. $\mathrm{OR} / 1-2$

4. MESH descriptor Pain, Postoperative

5. ((postoperative adj4 pain\$) or (post-operative adj4 pain\$) or post-operative-pain $\$$ or (post\$ NEAR pain\$) or (postoperative adj4 analgesi \$) or (post-operative adj4 analgesi\$) or ("post-operative analgesi\$")):ti,ab,kw.

6. ((post-surgical adj4 pain\$) or ("post surgical" adj4 pain\$) or (post-surgery adj4 pain\$)):ti,ab,kw.

7. (("pain-relief after surg\$") or ("pain following surg\$") or ("pain control after")):ti,ab,kw.

8. (("post surg\$" or post-surg\$) AND (pain\$ or discomfort)):ti,ab,kw.

9. ((pain\$ adj4 "after surg\$") or (pain\$ adj4 "after operat\$") or (pain\$ adj4 "follow\$ operat\$") or (pain\$ adj4 "follow\$ surg\$")):ti,ab,kw.

10.((analgesi\$ adj4 "after surg\$") or (analgesi\$ adj4 "after operat\$") or (analgesi\$ adj4 "follow\$ operat\$") or (analgesi\$ adj4 "follow\$ surg \$")):ti,ab,kw.

11.OR/4-10

12. Limit 11 to Clinical Trials (CENTRAL)

\section{Appendix 4. Glossary}

\section{Categorical rating scale}

The commonest is the five category scale (none, slight, moderate, good or lots, and complete). For analysis numbers are given to the verbal categories (for pain intensity, none $=0$, mild $=1$, moderate $=2$ and severe $=3$, and for relief none $=0$, slight $=1$, moderate $=2$, good or lots $=3$, and complete $=4$ ). Data from different participants are then combined to produce means (rarely medians) and measures of dispersion (usually standard errors of means). The validity of converting categories into numerical scores was checked by comparison with concurrent visual analogue scale measurements. Good correlation was found, especially between pain relief scales using cross-modality matching techniques. Results are usually reported as continuous data, mean or median pain relief or intensity. Few studies present results as discrete data, giving the number of participants who report a certain level of pain intensity or relief at any given assessment point. The main advantages of the categorical scales are that they are quick and simple. The small number of descriptors may force the scorer to choose a particular category when none describes the pain satisfactorily.

\section{Visual analogue scale (VAS)}

For pain intensity, lines with left end labelled "no pain" and right end labelled "worst pain imaginable", and for pain relief lines with left end labelled "no relief of pain" and right end labelled "complete relief of pain", seem to overcome the limitation of forcing patient descriptors into particular categories. Patients mark the line at the point which corresponds to their pain or pain relief. The scores are obtained by measuring the distance between the no relief end and the patient's mark, usually in millimetres. The main advantages of VAS are that they are simple and quick to score, avoid imprecise descriptive terms, and provide many points from which to choose. More concentration and co-ordination are needed, which can be difficult postoperatively or with neurological disorders.

\section{TOTPAR}

Total pain relief (TOTPAR) is calculated as the sum of pain relief scores over a period of time. If a patient had complete pain relief immediately after taking an analgesic, and maintained that level of pain relief for six hours, they would have a six-hour TOTPAR of the maximum of 24. Differences between pain relief values at the start and end of a measurement period are dealt with by the composite trapezoidal rule. This is a simple method that approximately calculates the definite integral of the area under the pain relief curve by calculating the sum of the areas of several trapezoids that together closely approximate to the area under the curve. 


\section{Summed pain intensity difference (SPID)}

SPID is calculated as the sum of the differences between the pain scores over a period of time. Differences between pain intensity values at the start and end of a measurement period are dealt with by the trapezoidal rule.

VAS TOTPAR and VAS SPID are visual analogue versions of TOTPAR and SPID.

See 'Measuring pain' in Bandolier's Little Book of Pain, Oxford University Press, Oxford. 2003; pp 7-13 (Moore 2003).

Appendix 5. Summary of outcomes in individual studies: efficacy

\begin{tabular}{|c|c|c|c|c|c|c|}
\hline & & Analgesia & & & Rescue med & cation \\
\hline Study ID & Treatment & PI or PR & $\begin{array}{l}\text { Number } \\
\text { with 50\% } \\
\text { PR }\end{array}$ & $\begin{array}{l}\text { PGE: very } \\
\text { good or ex- } \\
\text { cellent }\end{array}$ & $\begin{array}{l}\text { Median } \\
\text { time to use } \\
\text { (h) }\end{array}$ & $\%$ using \\
\hline Chang 2004 & $\begin{array}{l}\text { (1) etoricoxib } 120 \mathrm{mg}, \mathrm{n}=100 \\
\text { (2) oxycodone + paracetamol 10/650 } \\
\mathrm{mg}, \mathrm{n}=100 \\
\text { (3) placebo, } \mathrm{n}=25\end{array}$ & $\begin{array}{l}\text { TOTPAR 6: } \\
\text { (1) } 15.3 \\
\text { (3) } 4.1\end{array}$ & $\begin{array}{l}\text { (1) } 73 / 100 \\
\text { (3) } 3 / 25\end{array}$ & $\begin{array}{l}\text { At } 6 \mathrm{~h}: \\
\text { (1) } 61 / 98 \\
\text { (3) } 1 / 24\end{array}$ & $\begin{array}{l}(1)>24 \\
\text { (3) } 1.5\end{array}$ & $\begin{array}{l}\text { At } 6 \mathrm{~h}: \\
\text { (1) } 22 / 100 \\
\text { (3) } 18 / 25 \\
\text { At } 24 \mathrm{~h}: \\
\text { (1) } 45 / 100 \\
\text { (3) } 19 / 25\end{array}$ \\
\hline
\end{tabular}

\begin{tabular}{|c|c|c|c|c|c|c|}
\hline $\begin{array}{l}\text { Daniels } \\
2011\end{array}$ & $\begin{array}{l}\text { (1) etoricoxib } 90 \mathrm{mg}, \mathrm{n}=191 \\
\text { (2) etoricoxib } 120 \mathrm{mg}, \mathrm{n}=97 \\
\text { (3) ibuprofen } 600 \mathrm{mg}, \mathrm{n}=192 \text { (first } \\
\text { dose) }\end{array}$ & $\begin{array}{l}\text { TOTPAR 6: } \\
\text { (1) } 16.10 \\
\text { (2) } 15.73 \\
\text { (3) } 15.67 \\
\text { (4) } 11.83 \\
\text { (5) } 5.08\end{array}$ & $\begin{array}{l}\text { (1) } 148 / 191 \\
\text { (2) } 73 / 97 \\
\text { (5) } 8 / 46\end{array}$ & $\begin{array}{l}\text { At } 24 \mathrm{~h} \text { : } \\
\text { (1) } 117 / 191 \\
\text { (2) } 54 / 97 \\
\text { (5) } 8 / 46\end{array}$ & $\begin{array}{l}(1)>6 \\
(2)>6 \\
(3)>6 \\
(4)>6 \\
\text { (5) } 2.13\end{array}$ & $\begin{array}{l}\text { At } 6 \text { h: } \\
\text { (1) } 16 / 191 \\
\text { (2) } 12 / 97 \\
\text { (3) } 22 / 192 \\
\text { (4) } 22 / 62 \\
\text { (5) } 30 / 46\end{array}$ \\
\hline
\end{tabular}

(4) paracetamol/codeine 600/60 mg, $\mathrm{n}$

$=62$ (first dose)

(5) placebo, $n=46$

\begin{tabular}{|c|c|c|c|c|c|c|}
\hline \multirow[t]{5}{*}{$\begin{array}{l}\text { Malmstrom } \\
2004 a\end{array}$} & $\begin{array}{l}\text { (1) etoricoxib } 60 \mathrm{mg}, \mathrm{n}=75 \\
\text { (2) etoricoxib } 120 \mathrm{mg}, \mathrm{n}=76\end{array}$ & $\begin{array}{l}\text { TOTPAR 6: } \\
\text { (1) } 12.6\end{array}$ & $\begin{array}{l}\text { (1) } 44 / 75 \\
\text { (2) } 61 / 76\end{array}$ & $\begin{array}{l}\text { At } 8 \mathrm{~h}: \\
\text { (1) } 35 / 75\end{array}$ & $\begin{array}{l}\text { (1) } 12.1 \\
(2)>24\end{array}$ & $\begin{array}{l}\text { At } 24 \mathrm{~h}: \\
\text { (1) } 39 / 75\end{array}$ \\
\hline & (3) etoricoxib $180 \mathrm{mg}, \mathrm{n}=74$ & (2) 16.6 & (3) $64 / 74$ & (2) $48 / 76$ & $(3)>24$ & (2) $21 / 76$ \\
\hline & (4) etoricoxib $240 \mathrm{mg}, \mathrm{n}=76$ & (3) 17.6 & (4) $55 / 76$ & (3) $51 / 74$ & $(4)>24$ & (3) $19 / 74$ \\
\hline & (5) ibuprofen $400 \mathrm{mg}, \mathrm{n}=48$ & (4) 15.2 & (6) $6 / 49$ & (4) $51 / 76$ & (6) 2.1 & (4) $25 / 76$ \\
\hline & (6) placebo, $n=49$ & (6) 4.2 & & (6) $2 / 49$ & & (6) $40 / 49$ \\
\hline \multirow{3}{*}{$\begin{array}{l}\text { Malmstrom } \\
2004 b\end{array}$} & (1) etoricoxib $120 \mathrm{mg}, \mathrm{n}=50$ & TOTPAR 6: & (1) $37 / 50$ & At $8 \mathrm{~h}$ : & $(1)>24$ & At $24 \mathrm{~h}:$ \\
\hline & (2) sodium naproxen $550 \mathrm{mg}, \mathrm{n}=51$ & (1) 15.5 & (4) $6 / 50$ & (1) $34 / 50$ & (4) 1.6 & (1) $22 / 50$ \\
\hline & $\begin{array}{l}\text { (3) codeine + paracetamol } 60 / 600 \mathrm{mg} \text {, } \\
\mathrm{n}=50\end{array}$ & (4) 4.2 & & (4) $3 / 50$ & & (4) $45 / 50$ \\
\hline
\end{tabular}


(Continued)

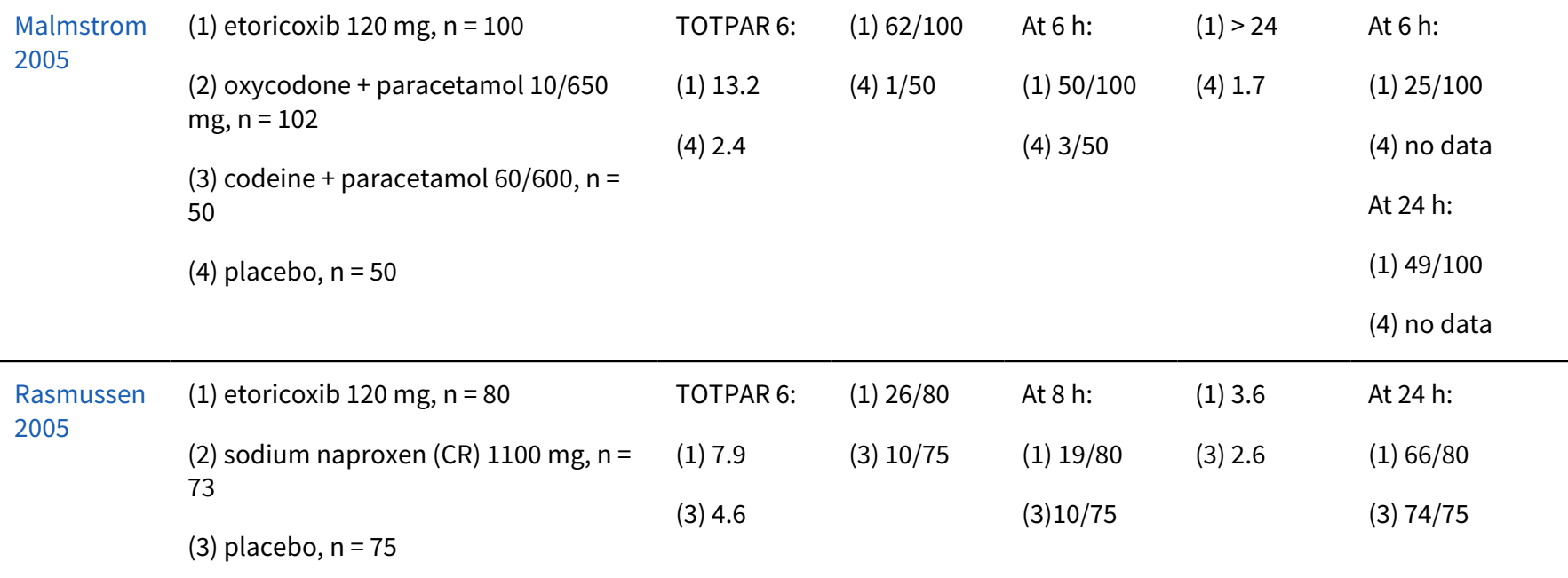

CR - controlled release; $\mathrm{n}$ - number in treatment arm; PI - pain intensity; PR - pain relief; PGE - patient global evaluation; TOTPAR 6 total pain relief at 6 hours

Appendix 6. Summary of outcomes in individual studies: adverse events and withdrawals

\begin{tabular}{|c|c|c|c|c|c|}
\hline & & Adverse eve & & Withdrawals & \\
\hline Study ID & Treatment & Any & Serious & $\begin{array}{l}\text { Adverse } \\
\text { event }\end{array}$ & Other \\
\hline Chang 2004 & $\begin{array}{l}\text { (1) etoricoxib } 120 \mathrm{mg}, \mathrm{n}=100 \\
\text { (2) oxycodone + paracetamol 10/650 } \\
\mathrm{mg}, \mathrm{n}=100 \\
\text { (3) placebo, } \mathrm{n}=25\end{array}$ & $\begin{array}{l}\text { At } 24 \text { hours: } \\
\text { (1) } 32 / 100 \\
\text { (3) } 6 / 25\end{array}$ & None & None reported & None reported \\
\hline Daniels 2011 & $\begin{array}{l}\text { (1) etoricoxib } 90 \mathrm{mg}, \mathrm{n}=191 \\
\text { (2) etoricoxib } 120 \mathrm{mg}, \mathrm{n}=97 \\
\text { (3) ibuprofen } 2400 \mathrm{mg} / \mathrm{day}, \mathrm{n}=192 \\
\text { (4) paracetamol/codeine } 2400 / 240 \mathrm{mg} / \\
\text { day, } \mathrm{n}=62 \\
\text { (5) placebo, } \mathrm{n}=46\end{array}$ & $\begin{array}{l}\text { At } 24 \mathrm{~h} \text { : } \\
\text { (1) } 54 / 191 \\
\text { (2) } 28 / 97 \\
\text { (5) } 12 / 46\end{array}$ & None & $\begin{array}{l}\text { (1) } 1 / 191 \\
\text { (2) } 0 / 97 \\
\text { (5) } 0 / 46\end{array}$ & None reported \\
\hline $\begin{array}{l}\text { Malmstrom } \\
2004 a\end{array}$ & $\begin{array}{l}\text { (1) etoricoxib } 60 \mathrm{mg}, \mathrm{n}=75 \\
\text { (2) etoricoxib } 120 \mathrm{mg}, \mathrm{n}=76 \\
\text { (3) etoricoxib } 180 \mathrm{mg}, \mathrm{n}=74 \\
\text { (4) etoricoxib } 240 \mathrm{mg}, \mathrm{n}=76 \\
\text { (5) ibuprofen } 400 \mathrm{mg}, \mathrm{n}=48 \\
\text { (6) placebo, } \mathrm{n}=49\end{array}$ & $\begin{array}{l}\text { At } 14 \text { days: } \\
\text { (1) } 24 / 75 \\
\text { (2) } 27 / 76 \\
\text { (3) } 31 / 74 \\
\text { (4) } 23 / 76 \\
\text { (6) } 24 / 49\end{array}$ & None & None & $\begin{array}{l}\text { Did not return for } \\
\text { post study visit: } \\
\text { (1) } 0 / 75 \\
\text { (2) } 0 / 76 \\
\text { (3) } 0 / 74 \\
\text { (4) } 2 / 76 \text { ( } 1 \text { with- } \\
\text { drew consent, } 1 \\
\text { lost to follow-up) }\end{array}$ \\
\hline
\end{tabular}




\begin{tabular}{|c|c|c|c|c|c|}
\hline $\begin{array}{l}\text { Malmstrom } \\
2004 \mathrm{~b}\end{array}$ & $\begin{array}{l}\text { (1) etoricoxib } 120 \mathrm{mg}, \mathrm{n}=50 \\
\text { (2) sodium naproxen } 550 \mathrm{mg}, \mathrm{n}=51 \\
\text { (3) codeine + paracetamol } 60 / 600 \mathrm{mg}, \mathrm{n} \\
=50 \\
\text { (4) placebo, } \mathrm{n}=50\end{array}$ & $\begin{array}{l}\text { At } 10 \text { days: } \\
\text { (1) } 13 / 50 \\
\text { (4) } 18 / 50\end{array}$ & None & None & $\begin{array}{l}\text { Did not return for } \\
\text { post study visit: } \\
\text { (1) } 1 / 50 \\
\text { (4) } 1 / 50\end{array}$ \\
\hline $\begin{array}{l}\text { Malmstrom } \\
2005\end{array}$ & $\begin{array}{l}\text { (1) etoricoxib } 120 \mathrm{mg}, \mathrm{n}=100 \\
\text { (2) oxycodone + paracetamol 10/650 } \\
\mathrm{mg}, \mathrm{n}=102 \\
\text { (3) codeine + paracetamol } 60 / 600, \mathrm{n}=50 \\
\text { (4) placebo, } \mathrm{n}=50\end{array}$ & $\begin{array}{l}\text { At } 7 \text { days: } \\
\text { (1) } 40 / 100 \\
\text { (4) } 19 / 50\end{array}$ & None & None reported & None reported \\
\hline $\begin{array}{l}\text { Rasmussen } \\
2005\end{array}$ & $\begin{array}{l}\text { (1) etoricoxib } 120 \mathrm{mg}, \mathrm{n}=80 \\
\text { (2) sodium naproxen (CR) } 1100 \mathrm{mg}, \mathrm{n}= \\
73 \\
\text { (3) placebo, } \mathrm{n}=75\end{array}$ & $\begin{array}{l}\text { No single dose } \\
\text { data }\end{array}$ & $\begin{array}{l}\text { No single dose } \\
\text { data }\end{array}$ & $\begin{array}{l}\text { No single dose } \\
\text { data }\end{array}$ & $\begin{array}{l}\text { (1) } 3 / 80 \\
\text { (3) } 10 / 75 \\
\text { (no details) }\end{array}$ \\
\hline
\end{tabular}

WHAT'S NEW

\begin{tabular}{lll}
\hline Date & Event & Description \\
\hline 29 May 2019 & Amended & Contact details updated. \\
\hline 11 October 2017 & Review declared as stable & No new studies likely to change the conclusions are expected. \\
\hline
\end{tabular}

\section{H I S T O R Y}

Protocol first published: Issue 3, 2003

Review first published: Issue 2, 2009

\begin{tabular}{lll}
\hline Date & Event & Description \\
\hline 9 May 2014 & Review declared as stable & This review will be assessed for further updating in 2019. \\
\hline 3 February 2014 & $\begin{array}{l}\text { New citation required but conclusions } \\
\text { have not changed }\end{array}$ & $\begin{array}{l}\text { No new studies identified and no additional data added. Con- } \\
\text { clusions unchanged, but Summary of findings table added and } \\
\text { quality of evidence made more explicit. Implications for practice } \\
\text { revised }\end{array}$ \\
\hline 31 January 2014 & New search has been performed & New searches run on 31 January 2014 \\
\hline 7 October 2013 & Amended & $\begin{array}{l}\text { Labels in forest plot for Analysis 1.2 corrected in response to } \\
\text { feedback from the Cochrane Editorial Unit }\end{array}$ \\
\hline
\end{tabular}




\begin{tabular}{lll}
\hline Date & Event & Description \\
\hline 12 March 2012 & $\begin{array}{l}\text { New citation required but conclusions } \\
\text { have not changed }\end{array}$ & $\begin{array}{l}\text { One study (Daniels 2011), previously identified as ongoing, now } \\
\text { published and added to review. Conclusions not changed }\end{array}$ \\
\hline 14 February 2012 & New search has been performed & New searches run \\
\hline 15 September 2011 & Review declared as stable & $\begin{array}{l}\text { The authors of this review searched the literature in August 2011 } \\
\text { and are confident that there will be no need to update this re- } \\
\text { view until at least 2015 }\end{array}$ \\
\hline
\end{tabular}

\section{CONTRIBUTIONS OFAUTHORS}

RC and SD were involved with searching, data extraction, quality scoring, analysis, and writing for the original review. RAM was involved with analysis and writing. HJM acted as arbitrator and was involved with writing.

SD ran searches for the updates, and both SD and RAM carried out data extraction and updated the analyses and text.

\section{DECLARATIONS OF INTEREST}

SD and RAM have received research support from charities, government and industry at various times, but none related to this review. RAM has consulted for, and received lecture fees from, various pharmaceutical companies related to analgesics and other healthcare interventions in the last five years. None relate to this review.

\section{SOURCES OF SUPPORT}

\section{Internal sources}

- Oxford Pain Relief Trust, UK.

General institutional support

\section{External sources}

- No sources of support supplied

\section{DIFFERENCES BETWEEN PROTOCOLANDREVIEW}

Since the protocol was published, 'Risk of bias' assessment and 'Summary of findings' tables have been introduced into Cochrane reviews. We have included them in this update.

\section{N DEX TERMS}

\section{Medical Subject Headings (MeSH)}

Acute Pain [ ${ }^{\star}$ drug therapy]; Administration, Oral; Cyclooxygenase 2 Inhibitors [ ${ }^{*}$ administration \& dosage] [adverse effects]; Etoricoxib; Pain, Postoperative [ ${ }^{\star}$ drug therapy]; Pyridines [ ${ }^{\star}$ administration \& dosage] [adverse effects]; Randomized Controlled Trials as Topic; Sulfones [*administration \& dosage] [adverse effects]; Toothache [drug therapy]

\section{MeSH check words}

Adult; Humans 